Article

\title{
Geochemistry and Geochronology of Southern Norilsk Intrusions, SW Siberian Traps
}

\author{
Elena Sereda ${ }^{1, *}$, Boris Belyatsky ${ }^{1}\left(\mathbb{C}\right.$ and Nadezhda Krivolutskaya ${ }^{2, *}$ \\ 1 A.P. Karpinsky Russian Geological Research Institute, Sredny prospect, 74, 199106 St.Petersburg, Russia; \\ bbelyatsky@mail.ru \\ 2 Vernadsky Institute of Geochemistry and Analytical Chemistry, Russian Academy of Sciences, Kosygin st., \\ 119991 Moscow, Russia \\ * Correspondence: nunatacky@mail.ru (E.S.); nakriv@mail.ru (N.K.); \\ Tel.: +7911-267-2806 (E.S.); +7926-543-4787 (N.K.)
}

Received: 25 November 2019; Accepted: 8 February 2020; Published: 13 February 2020

check for updates

\begin{abstract}
The Norilsk ore region is characterized by the occurrence of numerous intrusions comprising the PGE-Cu-Ni deposits. The Turumakit area, within the Southern Norilsk Trough, also contains many mineralized mafic intrusions of probably similar economic potential to the known Norilsk deposits. We study igneous rocks from three boreholes within the Turumakit area, sampling gabbro-dolerites and trachydolerites related to the Norilsk and Ergalakh complexes, as well as an outcrop of the Daldykan gabbro-dolerite intrusion. Our petrographical, mineralogical and geochemical data, as well as the $\mathrm{U}-\mathrm{Pb}$ dating of extracted baddeleyites and zircons, primarily discriminate between the sub-alkaline rocks of the main Turumakit area and the Ergalakh trachydolerites located in the Norilsk and Talnakh ore junctions. Coarser grained Turumakit trachydolerites (with pegmatite segregations) contrast finer grained Ergalakh trachydolerites by having: (1) higher $\mathrm{TiO}_{2}$ (up to $5.5 \mathrm{wt} \%$ ) compared with $2.2 \mathrm{wt} \%-3.3 \mathrm{wt} \%$ in the typical Ergalakh rocks; (2) low U, lower La/Yb and La/Sm ratios (5-7), in contrast to 8-10 ppm, 2.5-2.6 and 3.0-3.3, respectively, for the Ergalakh trachydolerites; and (3) their age was determined by $\mathrm{U}-\mathrm{Pb}$ methods on baddeleyite and zircon $(244.8 \pm 2.7 \mathrm{Ma})$, and it appears likely that the mafic rocks traditionally attributed to the Ergalakh complex within the Turumakit area are younger than the Norilsk intrusions $(250 \pm 1.4 \mathrm{Ma})$. These data strongly indicate an emplacement of Turumakit intrusions during the end of a $\sim 5 \mathrm{Myr}$ magmatic evolution of the Norilsk district. It is therefore proposed that the sub-alkaline rocks of the Turumakit area belong to a separate intrusive complex within the Norilsk district.
\end{abstract}

Keywords: Norilsk area; Siberian traps; sub-alkaline and mafic intrusions; U-Pb baddeleyite ages

\section{Introduction}

The Norilsk ore district known as a part of the large North Siberian metallogenic province [1] is located in the North-Western corner of the Siberian crystalline basement (AR; Figure 1), covered by stratified sedimentary and volcanic rocks [2,3]. It comprises many PGE-Cu-Ni deposits of varying reserves. The superlarge Octyabr'skoe and Talnakh deposits are located in the Southern Kharaelakh Trough, and the Norilsk 1 deposit is situated in the Northern Norilsk Trough (Figure 1). Within the Norilsk Trough there are also a number of moderate to smaller deposits, known as Chernogorsky, Norilsk 2 and Bol'shaya Bariernaya, among others.

The search for new deposits within the Norilsk district has challenged the Geological Survey for a number of years, and the southern part of the Norilsk trough is a prospective area, where Norilskgeologia LLC has drilled many boreholes that penetrate numerous intrusive bodies. 
These intrusions differ in composition and internal structures (Figure 2), but their subdivisions into magmatic complexes are often ambiguous, and may lead to unjustified complications with regards to correlations across the region. Thus, the Norilsk district geological map (scale 1:50,000; [4]) highlights several magmatic complexes (i.e., association of intrusive bodies with similar internal structure and composition), according to their alleged intrusion sequence (from older to younger): Ergalakh, Pyasinsky, Ogonersky, Norilsk, Morongovsky and Avamsky. While the first two and the last complexes are all subalkaline, the others have a tholeiitic composition. The ore-bearing Norilsk intrusive complex, further subdivided into the Lower Talnakh, Kruglogorsky, Norilsk and Zubovsky sub-complexes, includes several intrusions, with distinct cryptic and modal layering. Since all intrusions are hosted within the sedimentary rocks that underlie the Siberian Traps flood basalts, there are no cross-cutting relationships that may elucidate relative intrusive ages with these extrusives.

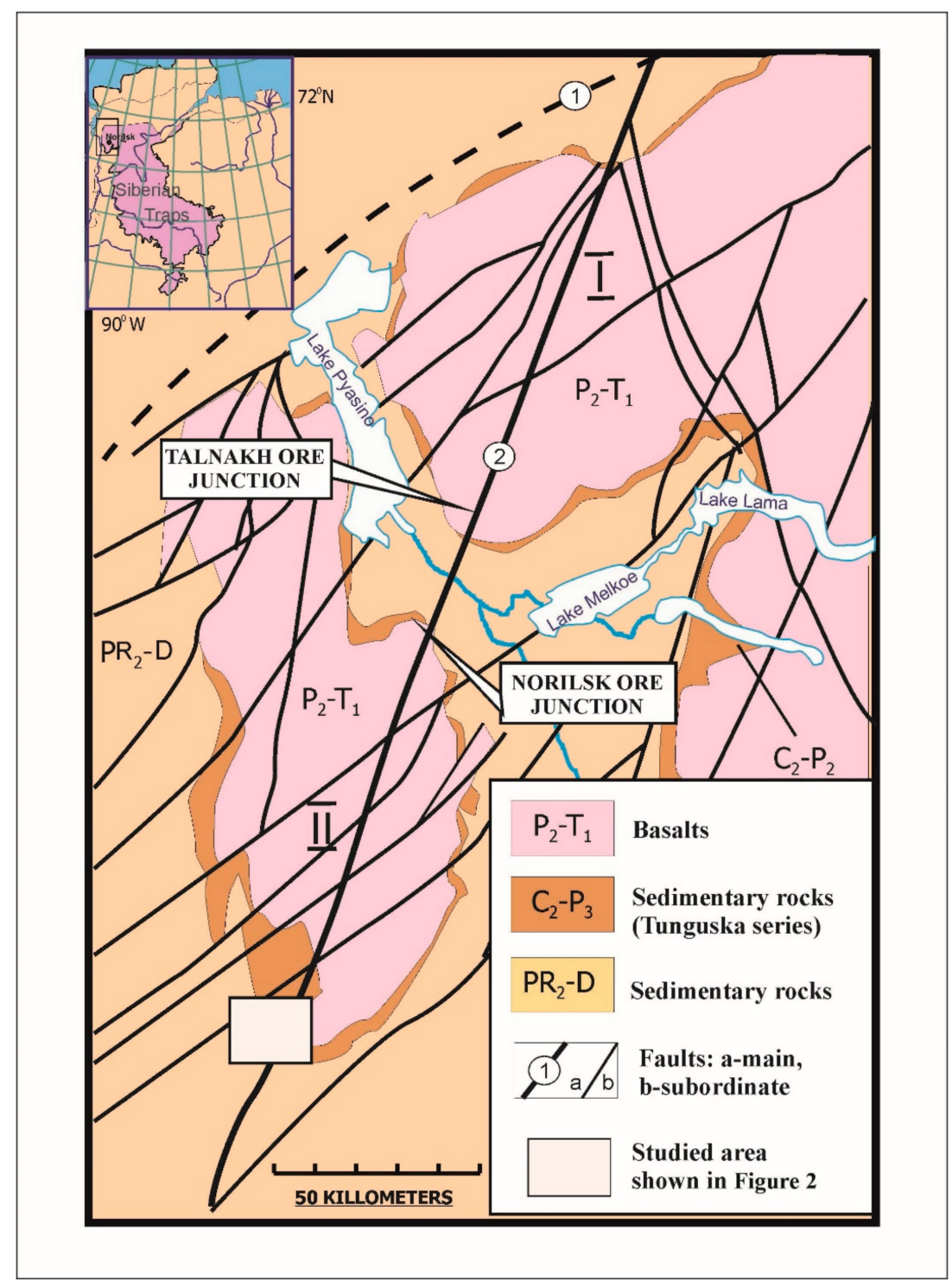

Figure 1. Geology of the Norilsk district (modified after [2]). Troughs: I-Kharaelakh, II-Norilsk; faults: 1-Yenisey-Khatangsky, 2-Norilsk-Kharaelakh. The sidebar shows the position of the Norilsk district within the Siberian traps province.

The sedimentary rocks comprise three structural units: (1) Proterozoic-Cambrian terrigenous strata, (2) Silurian-Devonian marine sediments and (3) Carboniferous-Lower Permian terrigenous 
coal-bearing sediments, collectively referred to as the Tunguska Series (Figure 1). Sedimentary rocks are overlapped by a $3.5 \mathrm{~km}$ thick Siberian Traps sequence of lavas and tuffs. The volcanic rocks are folded into several troughs, the main ones being the Kharaelakh (I) and Norilsk (II). PGE-Cu-Ni deposits are located in the intersections of these troughs with the large Norilsk-Kharaelakh fault (Figures 1 and 2).

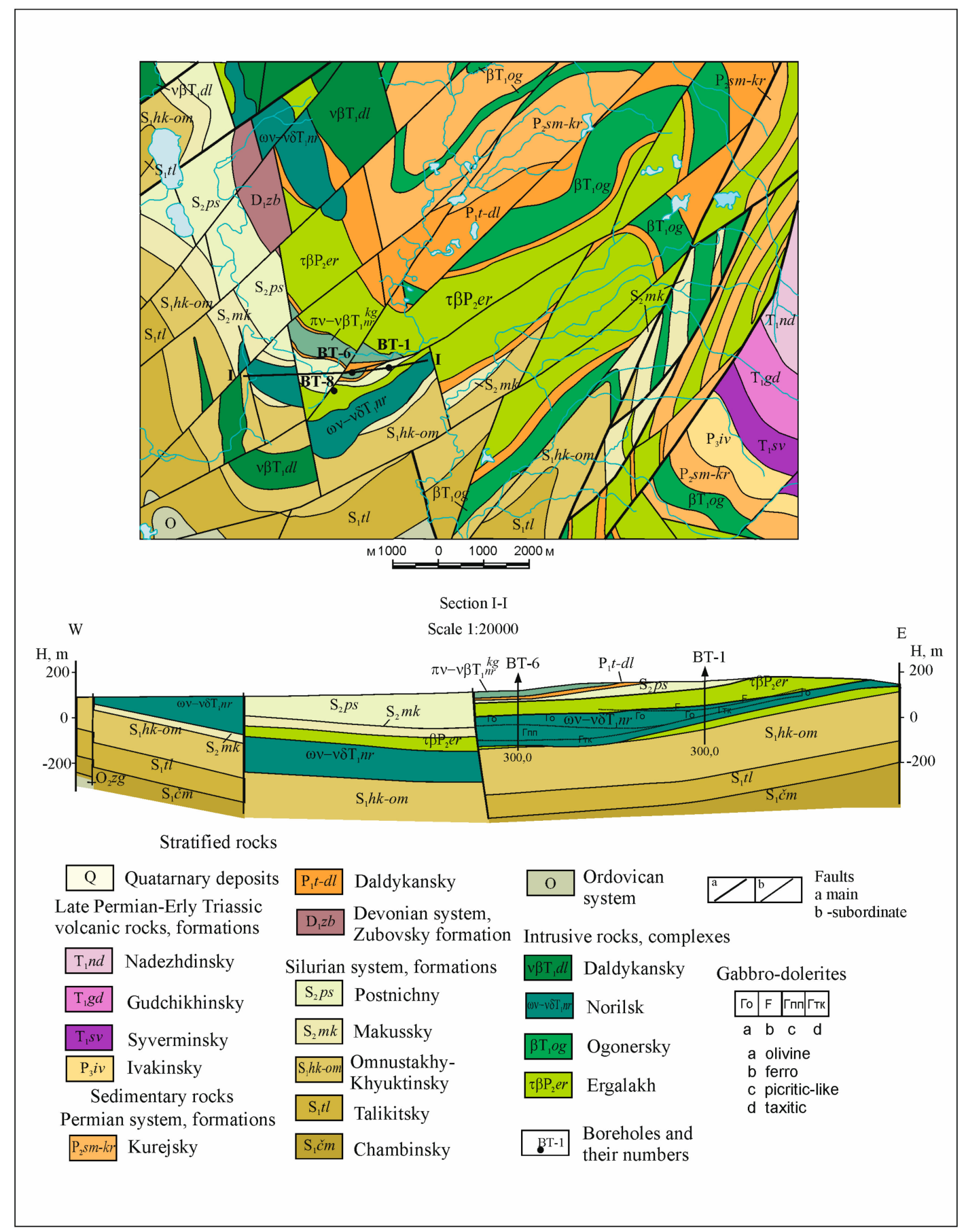

Figure 2. Geological map of the Turumakit area modified after Norilskgeologia LLC data.

The studied Turumakit area is located in the southern part of the Norilsk trough [4], where Silurian, Devonian and Permian sedimentary rocks are exposed at the surface (Figure 2). Siberian Traps' extrusive rocks (lavas and tuffs) only outcrop in the eastern part of this study area, and intrusive igneous rocks (mainly layered gabbro-dolerite bodies) comprise $25 \%$ of the area. Individual sills 
are correlated and combined into four intrusive complexes, based upon similar degrees of alkalinity, internal structures and mineral composition, which chronologically (from early to late) are Ergalakh, Ogonersky, Norilsk and Daldykan (Figure 2). Thus, the main task of the geological study of intrusions from the Turumakit was to compare them with well-studied intrusions of the Norilsk area and to attribute them to specific intrusive complexes. In order to investigate these complexes further and constrain their petrogenesis, differentiation and emplacement over time, we have carried out the petrographic and geochemical studies (including rare earth elements) of 65 samples from three drill-cores through the Ergalakh, Norilsk and Daldykan complexes, as well as baddeleyite and zircon $\mathrm{U}-\mathrm{Pb}$ ages and $\mathrm{Sr}-\mathrm{Nd}-\mathrm{Pb}-\mathrm{Os}$ isotopes of the Norilsk and Daldykan complexes (six samples).

\section{Materials and Methods}

We study Turumakit area core specimens attributed to the Ergalakh and Norilsk intrusions, which were collected from the boreholes BT-1, BT-6 and BT-8 (Figure 2), while the Daldykan intrusion is only represented by outcrop samples. Petrographical studies of thin sections were carried out with an Olympus microscope (Olympus Corporation, Tokyo, Japan), and the most representative and coarse-grained samples were selected for the separation of zircons and baddeleyites.

Major oxide concentrations of 65 samples were determined by X-ray fluorescence (XRF) at the Institute Geology of Ore Deposits, Petrography, Mineralogy and Geochemistry RAS (analyst A.I. Yakushev). This XRF machine, an AxiosmAX model from PANalytical (Almelo, The Netherlands), has a sequenced-action vacuum spectrometer (with dispersion over the wavelength), equipped with a $4 \mathrm{~kW}$ X-ray tube with an Rh-anode. The maximum voltage on the tube is $60 \mathrm{kV}$, and the maximum anode current is $160 \mathrm{~mA}$. The quality control of the results is carried out according to the analysis of rock standard samples (AGV-2 and BHVO-2, USGS). Results are presented in Table S1 and Table 1, and the relative standard deviations (RSDs) are as follows (\%): $\mathrm{SiO}_{2}: 0.12 ; \mathrm{TiO}_{2}: 0.05 ; \mathrm{Al}_{2} \mathrm{O}_{3}: 0.12$; $\mathrm{Fe}_{2} \mathrm{O}_{3}$ (total): 0.13; $\mathrm{MnO}$ : 0.005; $\mathrm{MgO}: 0.07 ; \mathrm{CaO}: 0.08 ; \mathrm{Na}_{2} \mathrm{O}: 0.08 ; \mathrm{K}_{2} \mathrm{O}: 0.03 ;$ and $\mathrm{P}_{2} \mathrm{O}_{5}: 0.01$.

Trace elements were analyzed by inductively coupled plasma mass spectrometry (ICP-MS, ThermoFisher Scientific, Waltham, MS, USA) at the Institute of Microelectronics Technology and High Purity Materials, Russian Academy of Sciences, Chernogolovka, Moscow, Russia, (analyst V.K. Karandashev). A $100 \mathrm{mg}$ powdered whole-rock sample was dissolved in $50 \mathrm{~mL}$ Teflon beakers with covers of watch-glass type (Halo Ploymer Kirovo-Chepetzk, Russia). We used $\mathrm{HNO}_{3}$ ( $65 \%$ nitric acid: max. $0.0000005 \% \mathrm{Hg}$, GR, ISO), HF (40\% hydrofluoric acid: GR, ISO, Merck, Germany), $\mathrm{HCl}$ (37\% hydrochloric acid: max. $0.0000005 \% \mathrm{Hg}$, PA-ACS-ISO: Panreac, Spain). Boric acid $\mathrm{H}_{3} \mathrm{BO}_{3}$ (GR for analysis: Merck, Germany) was used for the preparation of its $0.1 \mathrm{M}$ solution. In each batch, 2-3 control samples and one standard sample were simultaneously decomposed. Andesite AGV-2 and BHVO-2 (US Geological Survey) were used as standards. Determination of elements was performed with an X-7 quadruple mass spectrometer (ThermoFisher Scientific, Waltham, MS, USA) at the following parameters: plasma power of $1300 \mathrm{~W}$, set standard VeeSpray. Results are presented in Table S1 and Table 1. The lower limits of detection are as follows (ppm): Li: 0.02, Be: 0.01, Sc: 0.1, V: 0.8, Cr: 0.8, Co: 0.1, Ni: 0.6, Cu: 0.3, Zn: 0.4, Ga: 0.1, Rb: 0.08, Sr: 0.06, Y: 0.02, Zr: 0.07, Nb: 0.02, Cs: 0.005, Ba: 0.08, La: 0.01, Ce: 0.03, Pr: 0.01, Nd: 0.03, Sm: 0.01, Eu: 0.01, Gd: 0.01, Tb: 0.006, Dy: 0.007, Ho: 0.007, Er: 0.004, Tm: 0.002, Yb: 0.004, Lu: 0.006, Hf: 0.01, Ta: 0.01, Pb: 0.04, Th: 0.01, U: 0.005. Relative standard deviation (RSD) of element determinations are as follows (\%): $\mathrm{La}: 1 ; \mathrm{Rb}, \mathrm{Sr}, \mathrm{Y}, \mathrm{Ba}, \mathrm{Ce}, \mathrm{Pr}, \mathrm{Nd}, \mathrm{Er}, \mathrm{Th}, \mathrm{U}, \mathrm{Pb}, \mathrm{Ta}, \mathrm{Nb}$, $\mathrm{Zr}$ : all of these 2; Sm, Eu, Gd, Tb, Dy, Ho, Yb, Hf, Sc, Co, Ni, Cu, Zn: these all 3; and Lu, Tm: both 4 .

A water-based Wilfley table-technique, originally developed by [5], and adapted and modified in the laboratory of the Center of Isotope Research of the Karpinsky Geological Institute (VSEGEI, St. Petersburg, Russia), was used to separate a mono-mineral fraction of baddeleyite. The first important step for the successful liberation of baddeleyite from a hard-rock sample is a scanning of thin-sections of the sample with an electron microscope CamScan MX 2500S (CamScan Electron Optics, Finchley, London, United Kingdom). 
If at least one $>25 \mu \mathrm{m}$ baddeleyite crystal was identified, the sample was crushed to obtain a fraction less than $100 \mu \mathrm{m}$. The resulting powder was mixed with detergent and water and laid onto the shaking table. The densest concentrate was collected, from which the magnetic fraction was removed, and baddeleyites could be hand-picked from the heavy non-magnetic fraction under a binocular microscope. The baddeleyite crystals were implanted in epoxy resin (diameter $2.5 \mathrm{~cm}$ ) together with international Phalaborwa baddeleyite and 91,500 zircon mineral standards. Mounts were documented by a CamScan $\mathrm{M} \times 2500$ scanning electron microscope, while a CLI/QUA2 system produced back-scattered electron (BSE) and cathodoluminescent (CL) images to reveal the internal mineral structures and zonations.

Dating was carried out by a Secondary Ion Mass Spectrometry (SIMS) on a Sensitive High Resolution Ion Micro Probe (SHRIMP-II, ASI, Canberra, Australia) at the Center of Isotope Research of the Karpinsky Geological Institute (VSEGEI, St. Petersburg, Russia). This machine also measures the mineral concentrations of $\mathrm{U}, \mathrm{Th}, \mathrm{Pb}, \mathrm{Hf}$ and $\mathrm{REE}$. $\mathrm{U}-\mathrm{Pb}$ isotope ratios were measured according to the scheme described in [6], and adopted in Russia [7]. The SQUID 1.0 program [8] was used to calculate the raw-data. U-Pb Concordia diagrams [9] were constructed using the program ISOPLOT/EX [10]. Corrections for common lead were made using the measured ${ }^{208} \mathrm{~Pb}$ and the model isotopic composition of lead according to [11].

$\mathrm{Sr}, \mathrm{Nd}, \mathrm{Pb}$ and $\mathrm{Os}$ isotope ratios and $\mathrm{Rb}, \mathrm{Sr}, \mathrm{Sm}, \mathrm{Nd}$, Re and Os concentrations of whole rock samples were determined by isotopic dilution and were measured on a TRITON (ThermoFisher, Bremen, Germany) solid-state multicollector mass spectrometer at the CIR VSEGEI (St. Petersburg, Russia). The uncertainties of the measured ratios are given at two sigma levels together with results in Tables 2 and 3. A basalt BCR-2 was used as a standard sample for the Pb-Sr-Nd analytical work and serpentinite UB-N for standardization procedure for the Re-Os analysis. Details of this analytical procedure are described by [12].

\section{Results}

\subsection{Inner Structure and Petrography of Intrusions}

As indicated on the map and cross-section in Figure 2, intrusions previously attributed to the Ergalakh and Norilsk (nr) complexes are penetrated by boreholes BT-1, BT- 6 and BT-8, and are logged as shown in Figure 3.

The trachydolerites of the Ergalakh complex (er in Figures 2 and 3) are recognized on the basis of their elevated alkalinity, and are traditionally correlated with the Ivakinsky tuff-lava formation at the base of the Siberian Traps, with equally high alkalis and titanium [2,4,13-15]. This correlation is consistent with an absence of trachydoleritic sills within the Siberian Traps. However, there are some differences between typical Ergalakh rocks in the northern and central parts of the Norilsk district and those of the studied southern Turumakit area. First of all, trachydoleritic sills of the northern-central Ergalakh complex are usually thinner, darker and finer grained, while supposed Ergalakh rocks of the Turumakit area sills consist of paler and coarser grained trachygabbros, with numerous subalkaline pegmatite segregations $(515 \mathrm{~cm}$ ) with (vol \%) 55-60 plagioclase, 20-35 pyroxene, 0-12 olivine, 1-15 amphibole + chlorite, $0 \%-5 \%$ quartz, and up to $3 \%$ apatite, biotite, magnetite and ilmenite. Zircon and baddeleyite are only scarce accessory minerals.

Subalkaline rocks of the Ergalakh complex within the Turumakit area are represented by sill-like bodies reaching up $200 \mathrm{~m}$ in thickness and 10-20 km in length. Their thickness of the upper sill in the BT-1 borehole is $80 \mathrm{~m}$ (Figure 3) and the lower sill is penetrated to $25 \mathrm{~m}$. The absence of both an upper and lower chilled margin, typical of other Norilsk complex intrusions (Figure 3), do not provide field evidence on relative age relationships between intrusions. The mineral composition of the studied samples is as follows: olivine, pyroxenes and plagioclase are the main rock-forming minerals (Figure 4), and biotite, titanomagnetite and sulfides are subordinate. The main sulfides are represented by chalcopyrite, pyrrhotite and pentlandite; their concentration in the lower part of this 
intrusion is on average $1.5 \%-3 \%$, but sometimes reaches $5 \%-7 \%$. Of rare accessory minerals, apatite, zircon and baddeleyite are represented.

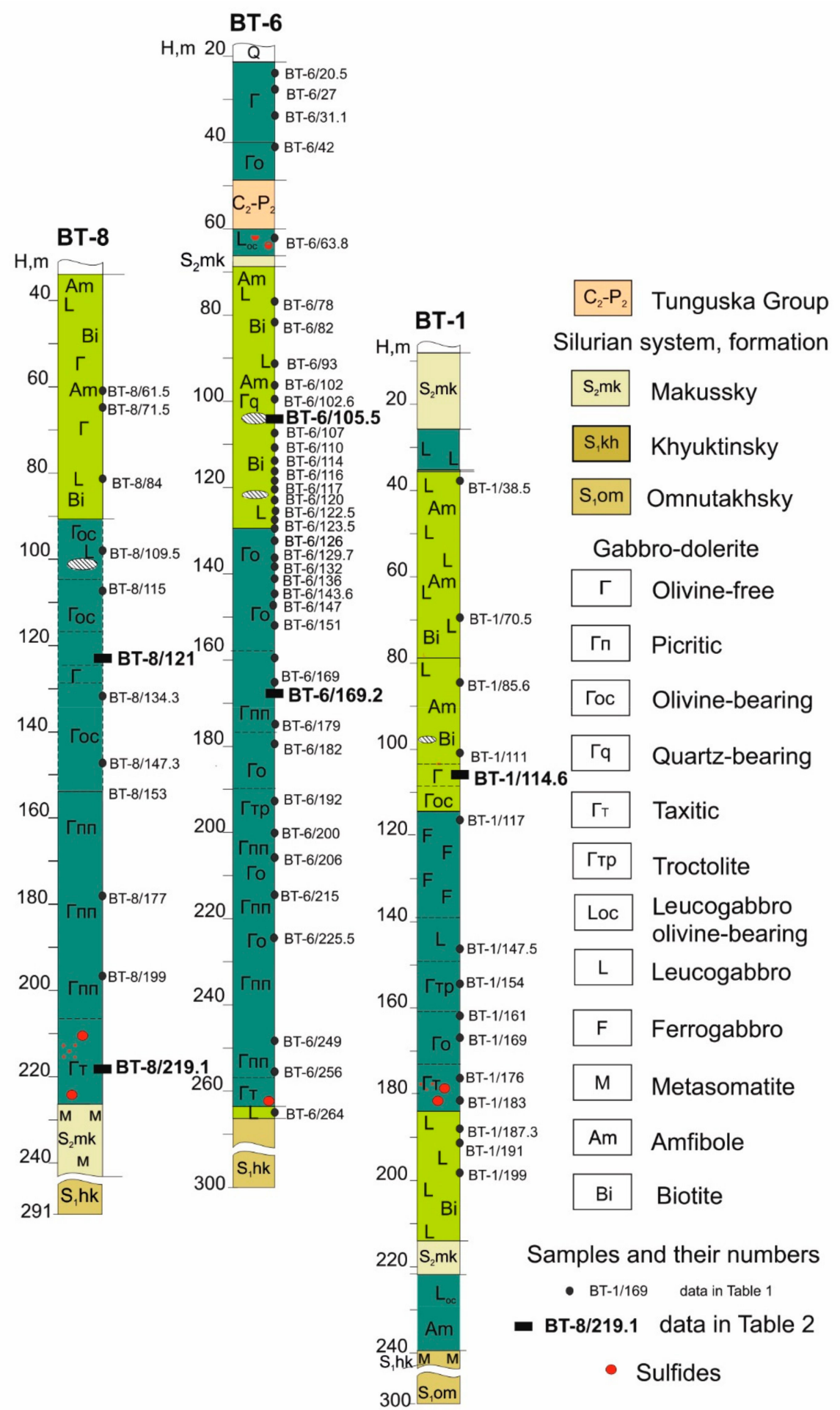

Figure 3. Inner structure of the intrusive bodies in the boreholes BT-1, BT- 6 and BT- 8 , and the relative location of the studied samples. The mineral composition of gabbro-dolerite is indicated by letter symbols in the lower right column. 

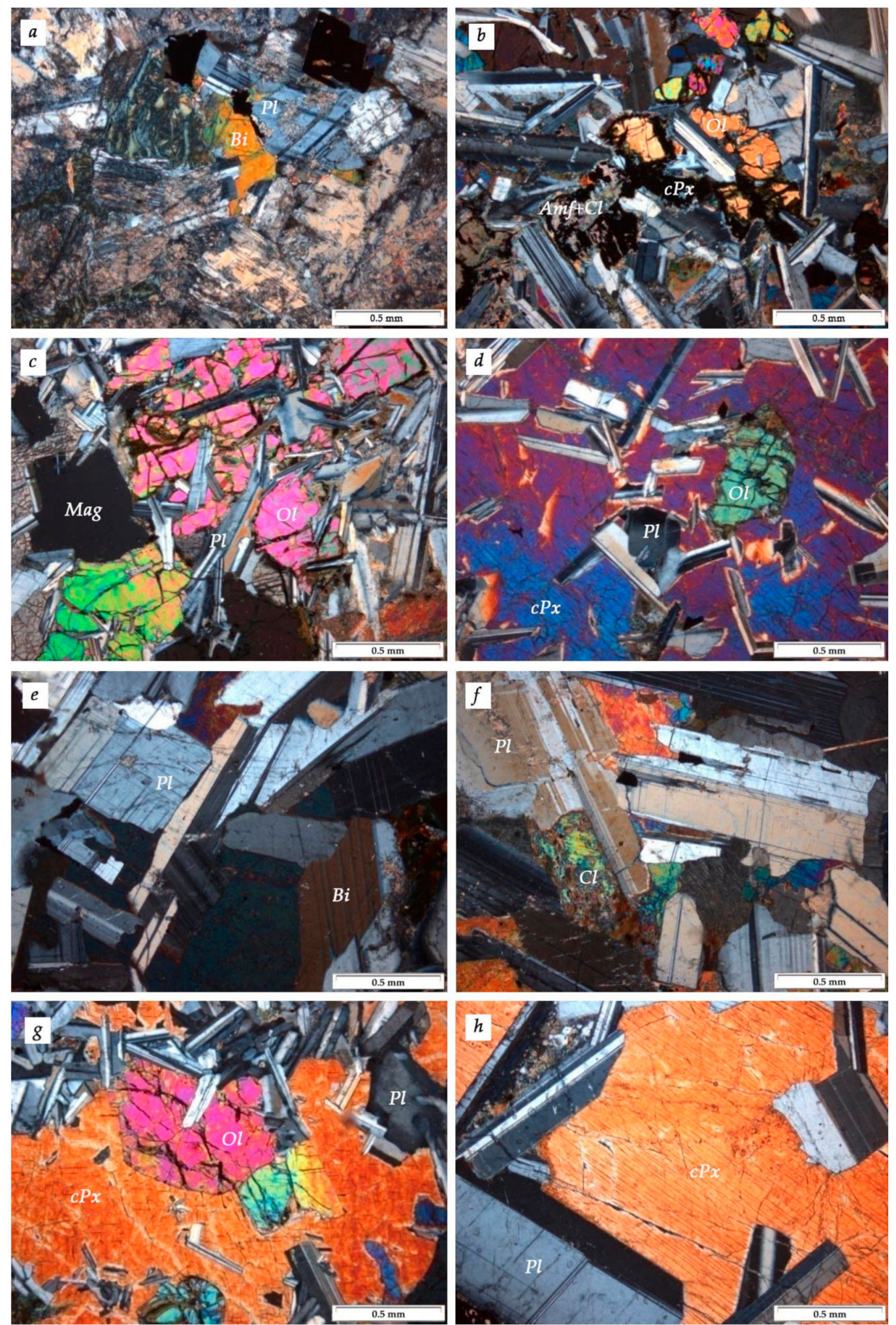

Figure 4. Photomicrographs of the intrusive rocks of the Turumakit area, borehole BT-6 and BT-8. Samples: (a,b) BT-6/90 biotite-amphibole bearing leucogabbro; (c,d) BT-8/97.4 olivine-bearing gabbro-dolerite; (e) BT-8/109 leucogabbro; (f,g) BT-8/134 olivine-bearing gabbro-dolerite; (h) BT-8/212 taxitic gabbro-dolerite (see relative position of the samples in the Figure 3); Minerals: $\mathrm{Ol}$-olivine, $c \mathrm{Px}$-clinopyroxene, $\mathrm{Pl}$-plagioclase, $\mathrm{Bi}$-biotite, $\mathrm{Mag}$ —-magnetite, Amf-amphibole. 
From the base to the top of logs in Figure 3, the Norilsk complex comprise taxitic (Figure 4h), picritic-like, olivine, olivine-bearing (Figure $4 \mathrm{c}, \mathrm{d}, \mathrm{f}, \mathrm{g}$ ) and olivine-free gabbros-dolerites; troctolites, leucogabbro and ferrogabbro; i.e., from basal olivine-rich (up 40 modal $\%$ of $\mathrm{Fo}_{74-68}$ ) cumulates to upper more evolved differentiates (olivine-bearing gabbro-dolerites) where $\mathrm{Fo}_{53-55}$ dominates. Plagioclase $\left(\mathrm{An}_{84-76}\right)$ also changes in both its habit and composition up through this layered sequence, crystallizing as the earliest liquidus phase, together with olivine and with olivine inclusions in the picritic gabbro-dolerites and troctolites. Clinopyroxenes form large zoned crystals (up to 5-6 $\mathrm{mm}$ ) with $\mathrm{Mg} \#=(100 \times \mathrm{MgO} /(\mathrm{MgO}+\mathrm{FeO}))=86-74(\mathrm{Mg} \#$ it is $\mathrm{Mg}$ number $)$ compositions that decreases 52 in the uppermost ferrogabbros. Sulfides are chalcopyrite, pyrrhotite and pentlandite, and their concentration in the lower part of this intrusion average $1.5 \%-3 \%$, but sometimes reaches $5 \%-7 \%$.

\subsection{Whole Rocks Composition}

The petrographic features established for the supposed Ergalakh intrusive rocks in the Turumakit area are confirmed by their chemical composition and differ from typical Ergalakh rocks of the Norilsk district. (Table S1 and Table 1; Figure 5). In the Turumakit area, the rocks of the Ergalakh intrusion consist of gabbro and leucogabbro with elevated alkalis, while the intrusions of the Norilsk complex are enriched in olivine, forming a separate field in the diagram Px-Pl-Ol. The points of analyses for the Norilsk rocks are located between gabbro and troctolite.

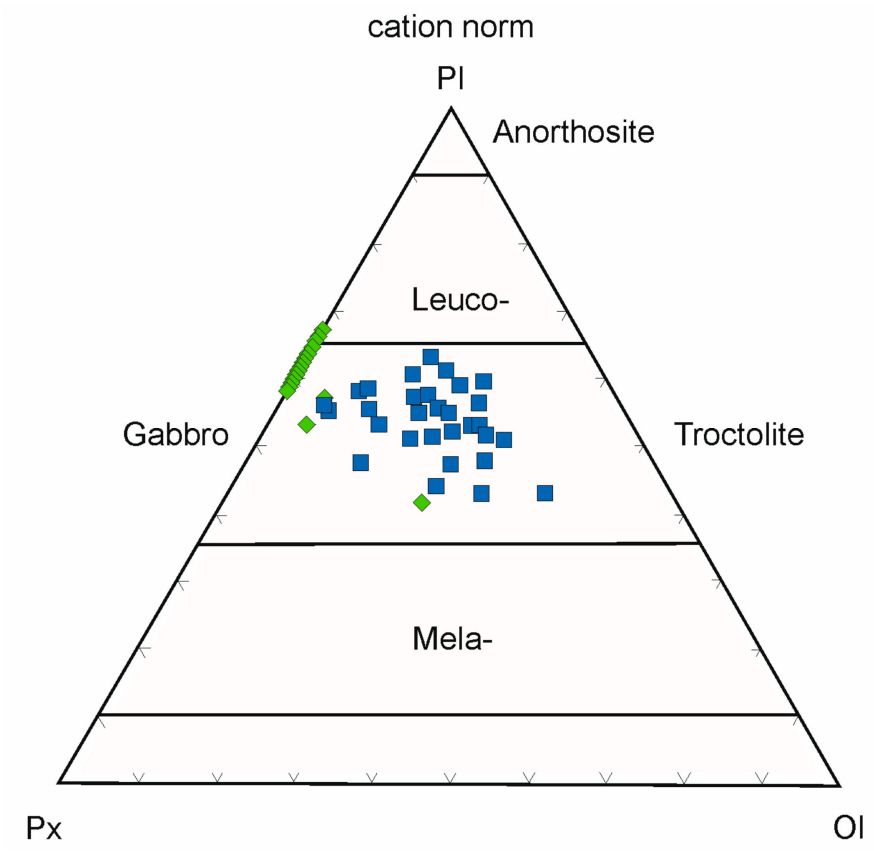

Figure 5. Px-Pl-Ol diagram for the Turumakit area rock compositions, where: blue squares and green diamonds correspond to samples from Norilsk and Ergalakh intrusions, respectively.

\subsubsection{Major Components}

To compare the studied rocks with typical rocks of the Ergalakh complex from the Kharaelakh trough and the Norilsk complex (the Norilsk 1 intrusion), we constrain series diagrams that demonstrate the behavior of major oxides during the crystallization reflected in $\mathrm{MgO}$ variations (Figure 6). 

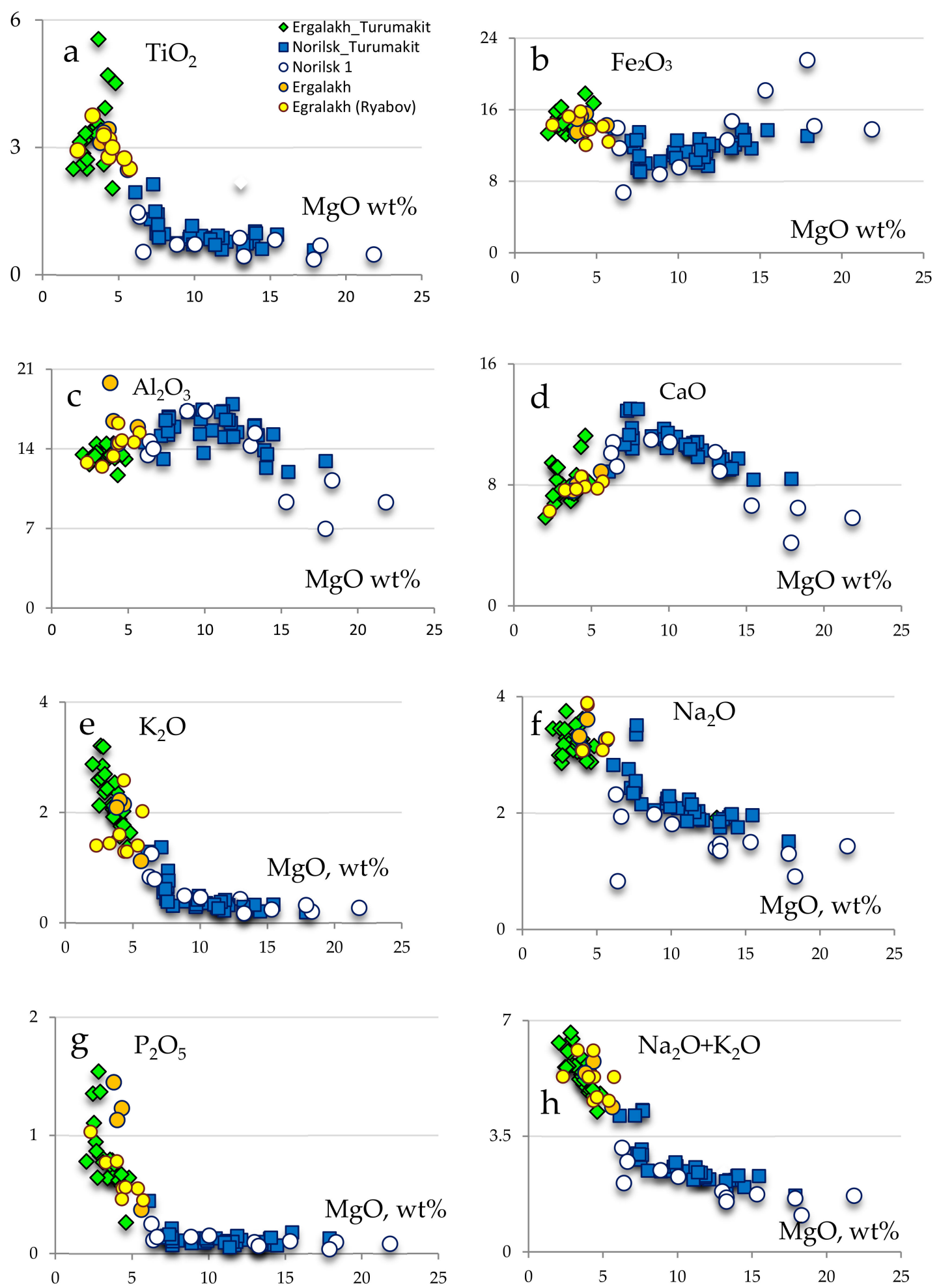

Figure 6. Cont. 

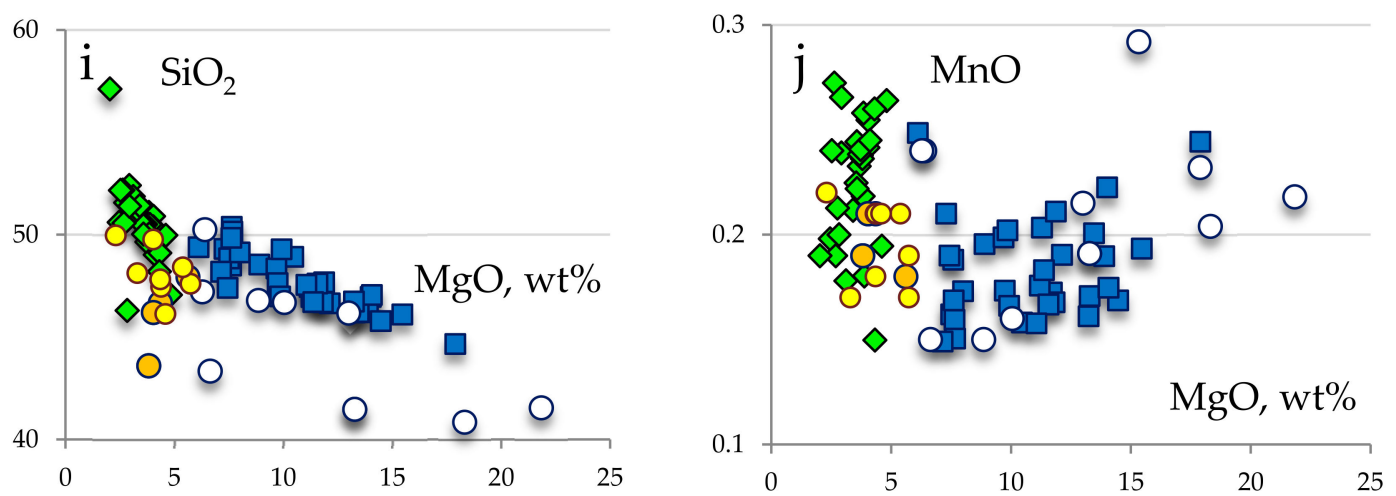

Figure 6. Oxides (a) $\mathrm{TiO}_{2}$, (b) $\mathrm{Fe}_{2} \mathrm{O}_{3}$, (c) $\mathrm{Al}_{2} \mathrm{O}_{3}$, (d) $\mathrm{CaO}$, (e) $\mathrm{K}_{2} \mathrm{O}$, (f) $\mathrm{Na}_{2} \mathrm{O}$, (g) $\mathrm{P}_{2} \mathrm{O}_{5}$, (h) $\mathrm{Na}_{2} \mathrm{O}+\mathrm{K}_{2} \mathrm{O}$, (i) $\mathrm{SiO}_{2}$, (j) $\mathrm{MnO}$ vs $\mathrm{MgO}$ (as a differentiation index) variation diagrams (wt \%). Data for Norilsk and Ergalakh (Turumakit area) are from Table S1 and Table 1; Norilsk 1 intrusion-unpublished authors' data, the Ergalakh data from the Kharaelakh trough-are from [16], Ergalakh (Ryabov)-data from the Ergalakh intrusion in the Norilsk trough [17].

The main distinguishing feature of the Ergalakh rocks in the Turumakit area is the high $\mathrm{TiO}_{2}$ content, which reaches $5.47 \mathrm{wt} \%$ and usually exceeds $3 \mathrm{wt} \%-3.5 \mathrm{wt} \%$ (Figure 6a). All Ergalakh samples are also characterized by elevated $\mathrm{FeO}$ content (Figure $6 \mathrm{~b}$ ) in comparison with the Norilsk samples that are enriched in $\mathrm{CaO}$ and $\mathrm{Al}_{2} \mathrm{O}_{3}$ (Figure $\left.6 c, d\right)$. The Ergalakh rocks in the Turumakit area also have a high alkali content (Figure $6 \mathrm{e}, \mathrm{f}), \mathrm{Na}_{2} \mathrm{O}+\mathrm{K}_{2} \mathrm{O}$ up to $6.7 \mathrm{wt} \%$. The elevated alkali contents in these rocks allow us to attribute them to coarser grained equivalents to volcanic trachybasalts or basaltic trachyandesites (Figure 6), while all samples from the Norilsk intrusive complex are basalts.

Concentrations of $\mathrm{P}_{2} \mathrm{O}_{5}$ in these rocks are high and from 0.64 to 1.54 (Figure $6 \mathrm{~g}$ ), and maximum $\mathrm{SiO}_{2}$ content is $57.1 \mathrm{wt} \%$ (Figure 6i). The Norilsk intrusions from the Turumakit region are characterized by higher $\mathrm{MgO}$ (up to $17.9 \mathrm{wt} \%$ ) and lower concentrations of $\mathrm{TiO}_{2}$, alkalis, $\mathrm{P}_{2} \mathrm{O}_{5}$ and $\mathrm{FeO}$. Figure 6a shows that the $\mathrm{TiO}_{2}$ content increases in the process of the fractionation of the primary melt in contrast to the supposed Ergalakh intrusion, in which high titanium is a primary characteristic. The composition comparison of the Ergalakh rocks in the Kharaelakh trough with those from the Turumakit demonstrates their similarity (Figure 6) in some oxides, i.e., $\mathrm{CaO}$ and $\mathrm{P}_{2} \mathrm{O}_{5}$, but there is a significant difference in $\mathrm{SiO}_{2}, \mathrm{Al}_{2} \mathrm{O}_{3}$ and $\mathrm{TiO}_{2}$.

The layered inner structure is reflected in the $\mathrm{MgO}$ distribution in rocks of the Norilsk complex (the example of borehole BT-6). The $\mathrm{MgO}$ content increases toward the lower contact of the intrusion (Figure 7), and there are some high picks reflecting the appearance of picritic and taxitic gabbro-dolerites in the section (depth 130-150 m, $190 \mathrm{~m}$ ). The upper part of this section is represented by olivine gabbro with $7 \mathrm{wt} \%-8 \mathrm{wt} \% \mathrm{MgO}$. It is suggested that these rocks belong to the same intrusive body into which the BT-6 borehole penetrated at a depth of 130-270 m and formed its upper endo-contact zone. Thus, we suggest that the single massif of the Norilsk complex was intruded by late trachydolerite magma of the Ergalakh complex. This assumption is also proven by the composition of the rocks: on the BT- 6 section (Figure 7) there is an interval from 70 down to $130 \mathrm{~m}$ with a low $\mathrm{MgO}$ ( $3 \mathrm{wt} \%-4 \mathrm{wt} \%$ ) as low as typical for Ergalakh trachydolerites. 


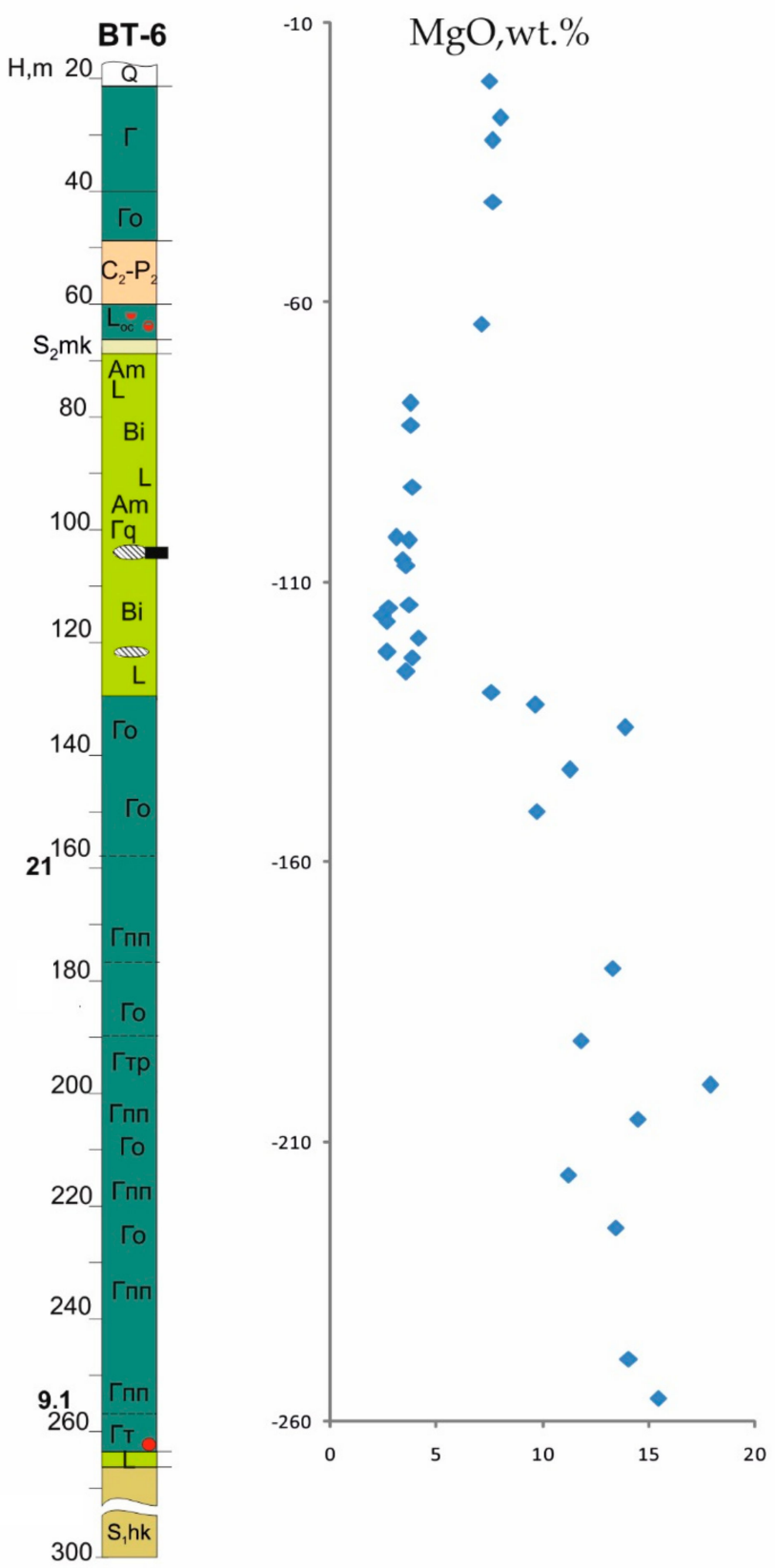

Figure 7. $\mathrm{MgO}$ (wt \%) distribution along the borehole BT-6 section.

\subsubsection{Trace Elements}

Trace element patterns also differ between the alleged Ergalakh and Norilsk intrusions of the Turumakit area. The supposed Ergalakh trachydolerites are more enriched in all incompatible elements compared to the cumulates of the Norilsk intrusion (Figure 8). Both complexes, however, are characterized by small, negative $\mathrm{Ta}-\mathrm{Nb}$ and positive $\mathrm{Pb}$ and $\mathrm{Sr}$ anomalies, where the latter may be attributed to plagioclase accumulation. Lower $\mathrm{Nb}-\mathrm{Ta}$ and elevated $\mathrm{Pb}$ are typical lithospheric signatures that could be derived from a lithospheric mantle and/or crustal assimilation.

The $(\mathrm{Gd} / \mathrm{Yb}) \mathrm{n}$ ratios of 1.9-2.0 and 1.2-1.3 for Ergalakh and Norilsk complexes suggest that their primary melts segregated from a deeper garnet- and a shallower spinel-bearing mantle source, respectively, as the boundary between garnet- and spinel-lherzolite sources passes through the value $(\mathrm{Gd} / \mathrm{Yb}) \mathrm{n}=2[18]$. 


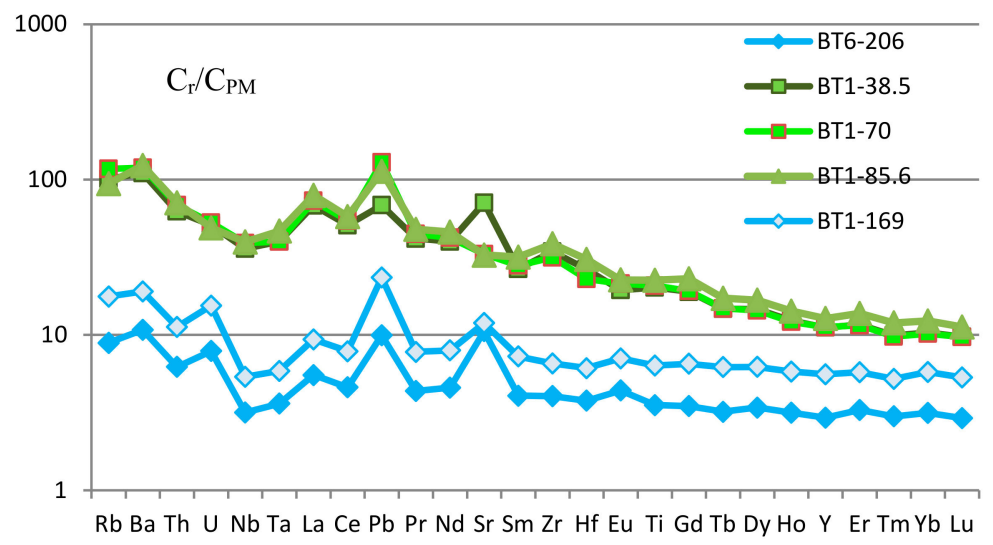

Figure 8. Spidergram for normalized [19] trace-element patterns of the rocks from the alleged Ergalakh (green lines) and Norilsk intrusions (blue lines) of the Turumakit area (data in Table S1).

\subsection{Age of Intrusive Rocks}

The following $\mathrm{U}-\mathrm{Pb}$ ages of the igneous rocks of the Ergalakh, Norilsk and Daldykan intrusions in the Turumakit area are based on a variable number of baddeleyites and zircons within six samples, the geochemical compositions and locations of which are provided in Table 1 and Figure 3.

Table 1. Bulk rock geochemical compositions of the Turumakit rock samples from which baddeleyites were separated.

\begin{tabular}{|c|c|c|c|c|c|c|}
\hline No. & 1 & 2 & 3 & 4 & 5 & 6 \\
\hline Sample & BT-1/114.6 & BT-6/105.5 & BT-8/121.9 & BT-8/219.1 & BT-6/169.2 & Dl-1 \\
\hline Complex & er & er & nr & nr & nr & dl \\
\hline $\mathrm{SiO}_{2}$ & 46.3 & 48.2 & 49.3 & 47.4 & 46.70 & 45.7 \\
\hline $\mathrm{TiO}_{2}$ & 3.33 & 4.7 & 2.13 & 1.49 & 0.71 & 2.02 \\
\hline $\mathrm{Al}_{2} \mathrm{O}_{3}$ & 13.4 & 11.7 & 13.1 & 16.5 & 16.56 & 15.3 \\
\hline $\mathrm{Fe}_{2} \mathrm{O}_{3}$ & 16.3 & 17.8 & 11.8 & 12.6 & 11.49 & 15.6 \\
\hline $\mathrm{MnO}$ & 0.2 & 0.26 & 0.21 & 0.19 & 0.18 & 0.22 \\
\hline $\mathrm{MgO}$ & 2.83 & 4.31 & 7.3 & 7.44 & 11.38 & 6.53 \\
\hline $\mathrm{CaO}$ & 9.16 & 8.13 & 12.9 & 11.3 & 10.35 & 10.1 \\
\hline $\mathrm{Na}_{2} \mathrm{O}$ & 3.44 & 2.89 & 2.43 & 2.34 & 2.15 & 2.95 \\
\hline $\mathrm{K}_{2} \mathrm{O}$ & 3.19 & 2.02 & 0.55 & 0.61 & 0.26 & 0.62 \\
\hline $\mathrm{P}_{2} \mathrm{O}_{5}$ & 1.54 & 0.67 & 0.15 & 0.16 & 0.05 & 0.21 \\
\hline LOI & 0.2 & 0.05 & 0.27 & 0.33 & 0.61 . & 0.61 \\
\hline $\mathrm{Cr}$ & 4.29 & 7.32 & 545 & 165 & 310 & 158 \\
\hline $\mathrm{Ni}$ & 5.33 & 9.38 & 79.5 & 134 & 320 & 118 \\
\hline $\mathrm{Rb}$ & 55.1 & 56.4 & 15.3 & 12.6 & 6.3 & 17.7 \\
\hline $\mathrm{Sr}$ & 1010 & 555 & 215 & 433 & 194 & 238 \\
\hline $\mathrm{Y}$ & 65.6 & 45.8 & 26.5 & 19.8 & 13.5 & 39.3 \\
\hline $\mathrm{Zr}$ & 394 & 278 & 81.5 & 72.6 & 57.4 & 135 \\
\hline $\mathrm{Nb}$ & 40.2 & 23.4 & 4.03 & 4.09 & 2,61 & 7.88 \\
\hline $\mathrm{Ba}$ & 1140 & 633 & 120 & 186 & 84 & 163 \\
\hline $\mathrm{La}$ & 70.5 & 40.4 & 8.05 & 7.27 & 4.83 & 11.1 \\
\hline $\mathrm{Ce}$ & 153 & 88 & 18 & 16.7 & 10.3 & 26.1 \\
\hline $\operatorname{Pr}$ & 19.2 & 10.9 & 2.62 & 2.21 & 1.41 & 3.62 \\
\hline $\mathrm{Nd}$ & 81.3 & 46.5 & 12.2 & 9.66 & 7.32 & 17.4 \\
\hline $\mathrm{Sm}$ & 17.2 & 10.5 & 3.61 & 3.03 & 2.04 & 5.04 \\
\hline $\mathrm{Eu}$ & 4.64 & 3.13 & 1.13 & 1.05 & 0.78 & 1.73 \\
\hline $\mathrm{Gd}$ & 17 & 10.4 & 3.98 & 2.84 & 2.74 & 6.13 \\
\hline $\mathrm{Tb}$ & 2.38 & 1.55 & 0.72 & 0.53 & 1.56 & 1.04 \\
\hline Dy & 13.4 & 8.88 & 4.53 & 3.5 & 2.72 & 6.66 \\
\hline
\end{tabular}


Table 1. Cont.

\begin{tabular}{ccccccc}
\hline No. & $\mathbf{1}$ & $\mathbf{2}$ & $\mathbf{3}$ & $\mathbf{4}$ & $\mathbf{5}$ & $\mathbf{6}$ \\
\hline Sample & BT-1/114.6 & BT-6/105.5 & BT-8/121.9 & BT-8/219.1 & BT-6/169.2 & Dl-1 \\
\hline Complex & er & er & $\mathbf{n r}$ & $\mathbf{n r}$ & $\mathbf{n r}$ & $\mathbf{d l}$ \\
\hline $\mathrm{Ho}$ & 2.55 & 1.68 & 0.98 & 0.75 & 0.56 & 1.41 \\
$\mathrm{Er}$ & 6.98 & 4.61 & 2.68 & 2.29 & 1.66 & 4.02 \\
$\mathrm{Tm}$ & 0.94 & 0.65 & 0.35 & 0.3 & 0.23 & 0.58 \\
$\mathrm{Yb}$ & 5.55 & 3.93 & 2.47 & 1.93 & 1.59 & 3.64 \\
$\mathrm{Lu}$ & 0.83 & 0.59 & 0.41 & 0.32 & 0.23 & 0.51 \\
$\mathrm{Hf}$ & 9.19 & 6.93 & 2.29 & 2.27 & 7.61 & 3.73 \\
$\mathrm{Ta}$ & 2.34 & 1.41 & 0.25 & 0.27 & 0.17 & 0.47 \\
$\mathrm{~Pb}$ & 11.3 & 7.9 & 3.89 & 1.87 & 1.07 & 4.5 \\
$\mathrm{Th}$ & 6.36 & 4.59 & 1.11 & 1.1 & 0.68 & 1.38 \\
$\mathrm{U}$ & 1.83 & 1.22 & 0.42 & 0.47 & 0.20 & 0.58 \\
\hline
\end{tabular}

Note: Complex: nr: Norilsk, er: Ergalakh, dl: Daldykan intrusions.

\subsubsection{Ergalakh Intrusion in Turumakit Area}

Baddeleyite and zircon were separated from coarse-grained trachydolerite samples BT-1/114.6 and BT-6/105.5 (Figure 9a,b). From the first sample we have separated 20 baddeleyite grains, which are represented by the elongated and almost isometric fragments of lamellar crystals, from 50 to $150 \mu \mathrm{m}$ in length (Figure 10). Its color changes from light (grains 11.1 and 13.1, Figure 11) to dark brown (19.1, Figure 10). They are transparent (17.1) and translucent (3.1), sometimes fractured (10.1,15.1), with characteristic shading along the elongation of crystals (16.1) and stepped relief $(8.1,18.1)$. Single crystals have well distinguished prism [011] faces $(13.1,7.1)$. The U-Pb system of the studied baddeleyite grains is marked by high $\mathrm{U}(300-3000 \mathrm{ppm})$ and low Th (2-350 ppm), and a sufficiently high radiogenic ${ }^{206} \mathrm{~Pb}(10-110 \mathrm{ppm})$, which translates to low analytical errors of measured isotopic ratios.

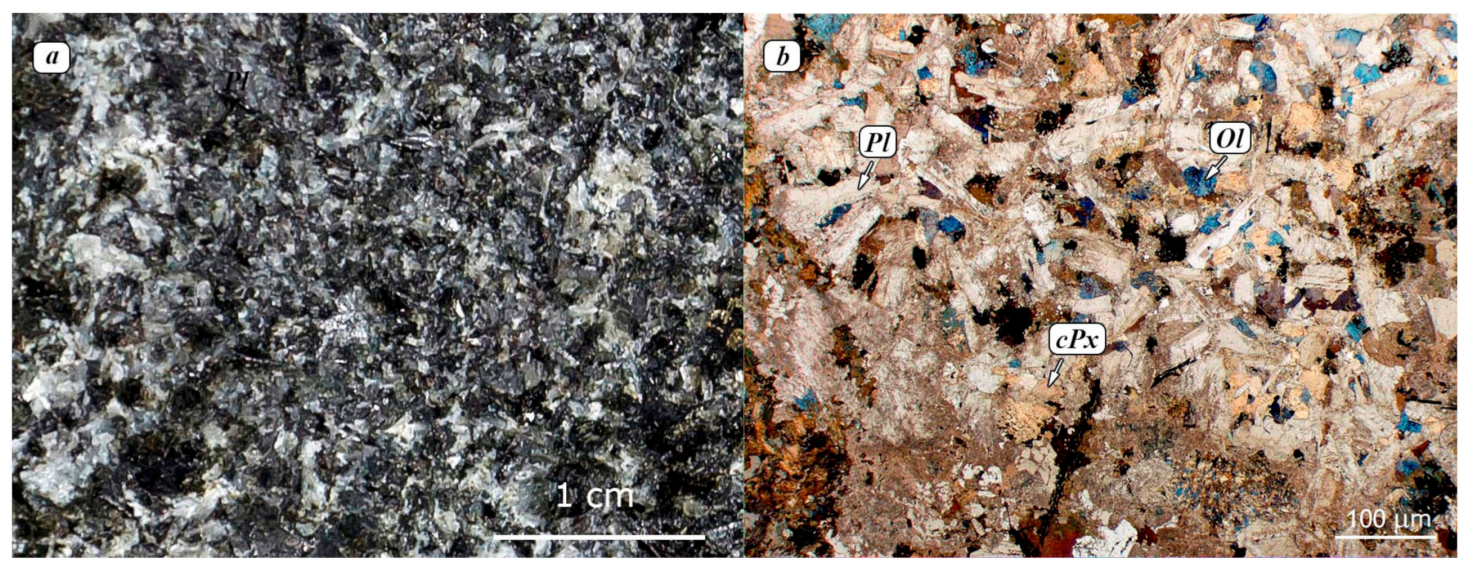

Figure 9. Hand specimen photo (a) and microphotogaph (b) of sample BT-1/114.6 trachydolerite (Pl: plagioclase, $c P x$ : clinopyroxene, $\mathrm{Ol}$ : olivine). 

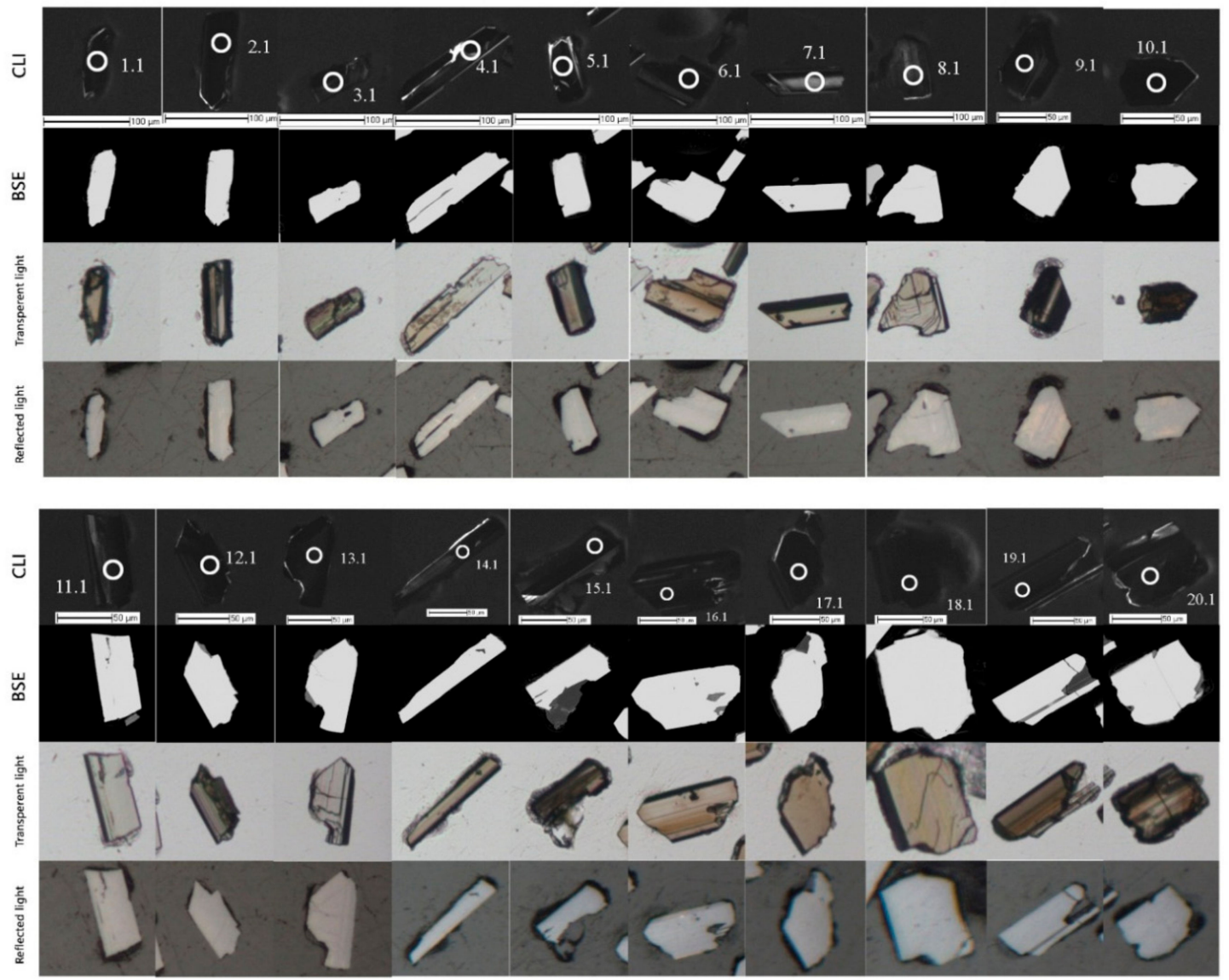

Figure 10. Baddeleyite grains from the trachydolerite sample BT-1/114.6. Rows (1-8 from top to bottom): 1 row-grains 1-10 in CLI, 3 row)-grains 1-10 in back-scattered electron (BSE), 3 row-grains 1-10 in transparent light, 4 row-grains 1-10 in reflected light; 5 row-grains 11-20 in CLI, 6 row-grains 11-20 in BSE, 7 row-grains 11-20 in transparent light, 8 row-grains 11-20 in reflected light.

The estimated concordant age for BT-1/114.6 trachydolerite based on 18 out of $20 \mathrm{U}-\mathrm{Pb}$ analyses of baddeleyite is $245.3 \pm 3.0 \mathrm{Ma}$ (Figure 11a) if the correction for the share of common $\mathrm{Pb}$ was made with the assumption of ${ }^{206} \mathrm{~Pb} /{ }^{238} \mathrm{U}$ and ${ }^{208} \mathrm{~Pb} /{ }^{232} \mathrm{Th}$ age-concordance $\left({ }^{208} \mathrm{~Pb}\right.$ correction-method). From the second BT-6/105.5 trachydolerite sample, several baddeleyite grains coated with a polycrystalline micro-zircon shell were selected for U-Pb isotopic analysis. In some cases, the morphology of the baddeleyite crystals is preserved, but the grain composition corresponds to zircon, presumably reflecting the replacement of baddeleyite with zircon with an increase in silicic activity during the evolution of magmatic melt. We tried to perform an isotopic analysis separately on the surviving baddeleyite matrix or on the newly formed zircons, but the U-Pb system for both analyzed minerals turned out to be almost identical (U from 500 to $4000 \mathrm{ppm}$ for baddeleyite and 570-2150 ppm for zircon, and Th 40-3100 and 450-5460 ppm, radiogenic ${ }^{206} \mathrm{~Pb} 15-130$ and 10-90 ppm, Th/U: 0.1-0.9 and 0.6-2.8, respectively). Thus, two ages based on (1) three zircon analyses and (2) 10 baddeleyite analyses (Figure 11b) give similar values within their limits of uncertainty $245.2 \pm 8.7$ and $240.6 \pm 7.9 \mathrm{Ma}$, respectively. Recalculation by the sum of all 13 analyses leads to a date of $244.3 \pm 4.5 \mathrm{Ma}$, which is also indistinguishable from the corresponding value for another trachydolerite sample BT-1/114.6.

The best age estimation of the Ergalakh intrusion crystallization can be obtained for all $31 \mathrm{U}-\mathrm{Pb}$ SHRIMP-II isotopic analyses of baddeleyite and zircon from both samples, namely $244.8 \pm 2.7 \mathrm{Ma}$ (Figure 11c). 

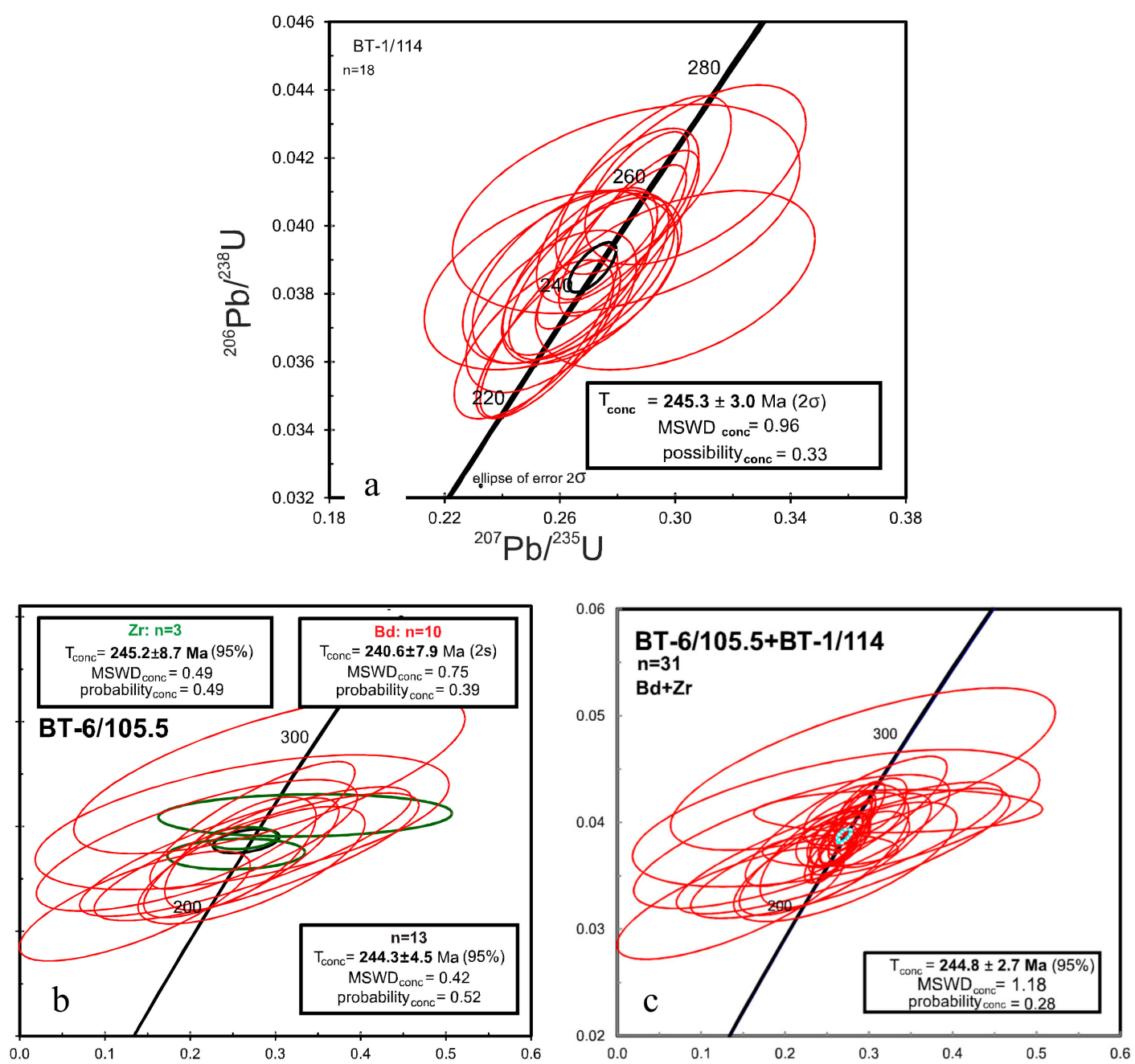

Figure 11. The U-Pb diagrams with Concordia for baddeleyite (red) and zircon (green) from trachydolerites of samples BT-1/114.6 (a) and BT-6/105.5 (b) and for a total of 31 concordant data-points from these samples (c). Reported ellipses correspond to a $95 \%$ level of confidence of analytical data.

\subsubsection{Norilsk Intrusions}

Baddeleyites from two samples of gabbro-dolerites from the Norilsk-type intrusions (Figure 12), BT-8/121.9 and BT-8/219.1, are similar, and do not differ in appearance from that shown in Figure 9.

In the first sample, baddeleyite is represented by light brown, transparent, elongated and isometric fragments of plate crystals with a size of 50-100 $\mu \mathrm{m}$. Individual crystals have a characteristic hatching (6.1) and prism faces [011] $(4.1,6.1)$. In the second sample BT-8/219.1, finer grains ranging in size from 50 to $80 \mu \mathrm{m}$, elongated and irregular fragments of plate crystals from light to saturated brown were found. Separate grains have a characteristic hatching (6.1), a stepped relief (10.1) and a prism faces [011] (6.1).

$15 \mathrm{U}-\mathrm{Pb}$ SHRIMP-analyses on 13 baddeleyite grains were performed for the BT-8/121.9 gabbro-dolerite. Their uranium and thorium contents varied between 100-1200 and 2-70 ppm, respectively, and the $\mathrm{Th} / \mathrm{U}$ ratio also varied between 0.01 and 0.1 . While the proportion of non-radiogenic lead did not exceed $1.6 \%$, radiogenic ${ }^{206} \mathrm{~Pb}$ only varied in the range $3-40 \mathrm{ppm}$, and this made it possible to measure radiogenic ${ }^{206} \mathrm{~Pb}$ to ${ }^{238} \mathrm{U}$ ratios with an error of less than $2.6 \%-4.5 \%$ ( $1 \sigma$ confidence level). Moreover, all data-points are concordant within this error range (Figure 13a), but are distributed alongside the Concordia line from 220 to 280 Ma due to a non-perfect matrix-matched or crystal-lattice orientation effect. The age of $251.2 \pm 5.7$ Ma was obtained from 14 out of 15 analyses, with an MSWD 
of 0.3 and a concordance probability of 0.56 . The exception of grain 9 , with very poor and inconsistent lead emissions, gives a slightly lower concordant age of 249.2 \pm 4.1 Ma (MSWD 0.2, probability 0.6, 13 analyses, Figure 11a). If we only use 11 analyses with the least individual errors, then the resulting concordant age is a $251.8 \pm 4.3 \mathrm{Ma}$ (with an MSWD of 0.1 and a probability of concordance of 0.7 ).
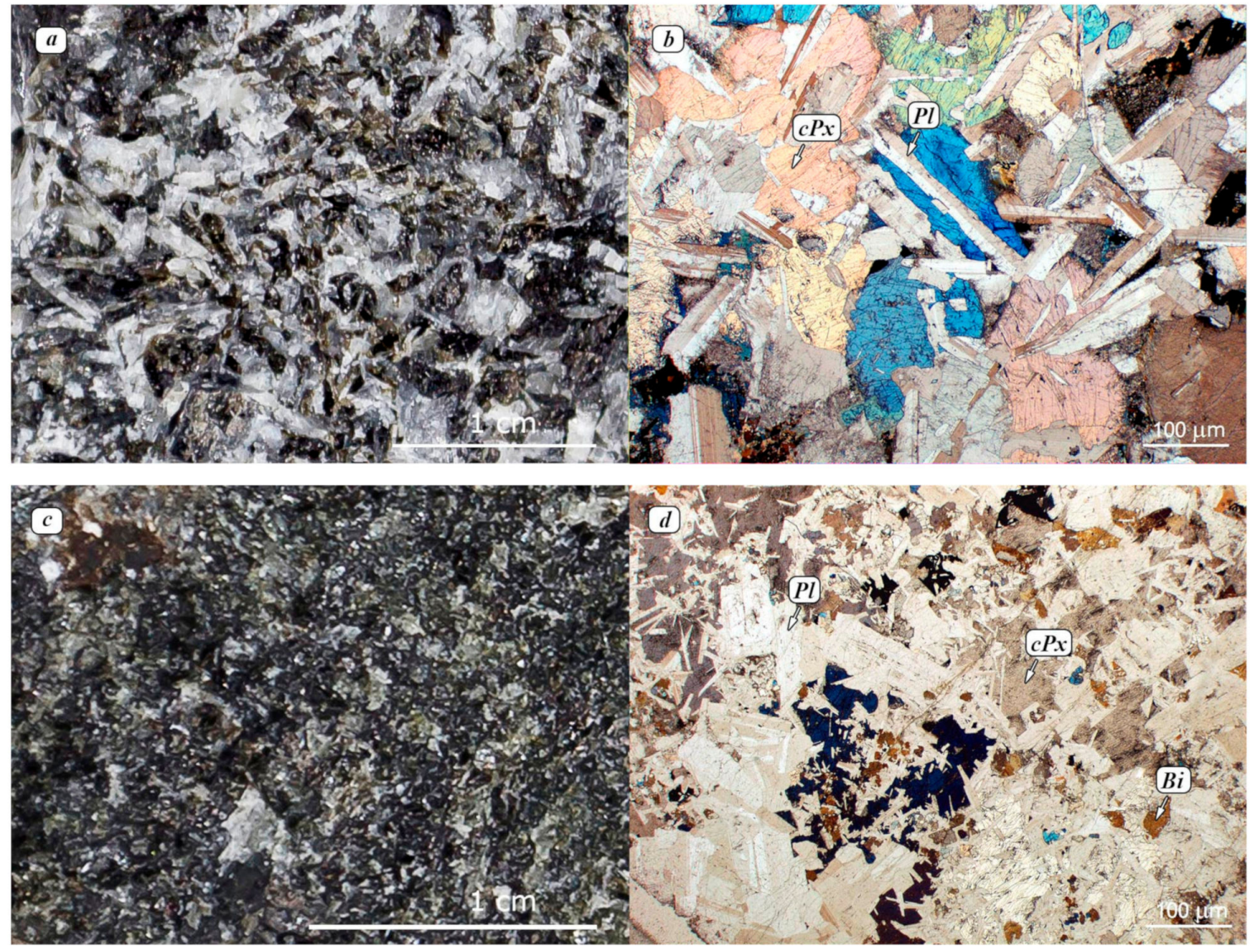

Figure 12. Photo and photomicrographs of gabbro-dolerites, samples BT-8/121.9 (a,b) and BT-8/219.1 (c,d).
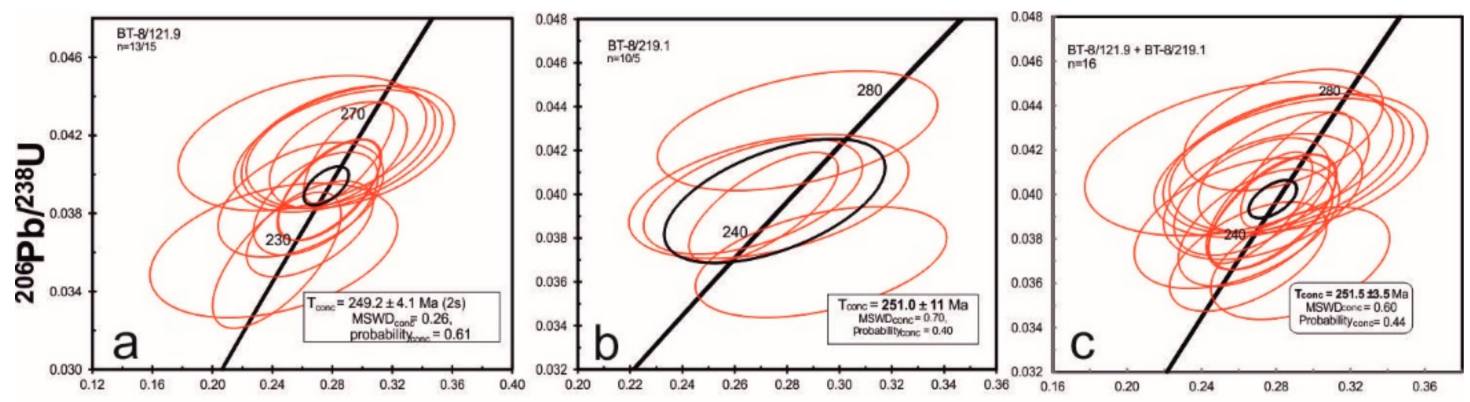

${ }^{207} \mathrm{~Pb} /{ }^{235} \mathrm{U}$

Figure 13. The U-Pb diagrams with concordia for baddeleyite from the gabbro-dolerites of samples BT-8/121.9 (a) and BT-8/219.1 (b), and summary for 16 concordant data-points from these samples (c) Reported ellipses correspond to a $95 \%$ level of confidence of analytical data.

In the case of BT-8/219.1 gabbro-dolerite, the U-Pb local analysis was carried out on all 10 separated baddeleyite grains, but the small grain size and mainly low $\mathrm{Pb}$ radiogenic content (as low as 1.5-36 ppm) led to sufficiently large analytical errors (up to $7 \%-8 \%$ in the ${ }^{207} \mathrm{~Pb} /{ }^{206} \mathrm{~Pb}$ ratio). While other characteristics of the U-Pb isotope system of this baddeleyite are very similar to those that have baddeleyite BT-8/121.9, the U varies from 150 to 1000 ppm, Th from 2 to 100 ppm, common Pb from 0.2 
to $1.5 \%$ and ${ }^{206} \mathrm{~Pb} /{ }^{238} \mathrm{U}$ ages ranges from 200 to $280 \mathrm{Ma}$. This leads to concordant age estimation with increased uncertainty of $251.0 \pm 11$ Ma for the most consistent cluster of the 5 out of 10 data-points (Figure 13b).

Combining $16 \mathrm{U}-\mathrm{Pb}$ baddeleyite analyses from both Norilsk intrusion samples provides a concordant age of $251.5 \pm 3.5 \mathrm{Ma}$, which is preferred as the best age estimation for the time of the Norilsk intrusion formation (Figure 13c).

\subsubsection{Daldykan Intrusion}

Mainly zircon was separated from the Daldykan gabbro-dolerite sample DL-1 (Figures 14 and 15), but a more thorough search revealed individual brownish thin-plate baddeleyite crystals among these zircon fractions. It should be noted there are no reaction shells and zones of baddeleyite substitution after zircon, and conversely, a polycrystalline zircon crust is absent on baddeleyite grains, and both are often recorded in mafic rocks as a consequence of changes in the melt composition during magma evolution [20]. Zircon grains in this rock are represented by fragments of prismatic crystals from elongated (grains 8.1 and 9.1) to almost isometric (1.1) and irregular (4.1) morphology (Figure 15). The dipyramid [111] faces are clearly distinguishable in individual grains (10.1). There are also twinning crystals (3.1). Grain sizes change from 80 to $150 \mu \mathrm{m}$, color varies from colorless to dark brown. Transparent (7.1) and translucent $(1.1,3.1)$, partly fractured $(9.1,2.1)$ and with the different kinds of inclusions (6.1) 8 zircon grains were dated by U-Pb SHRIMP-II method.

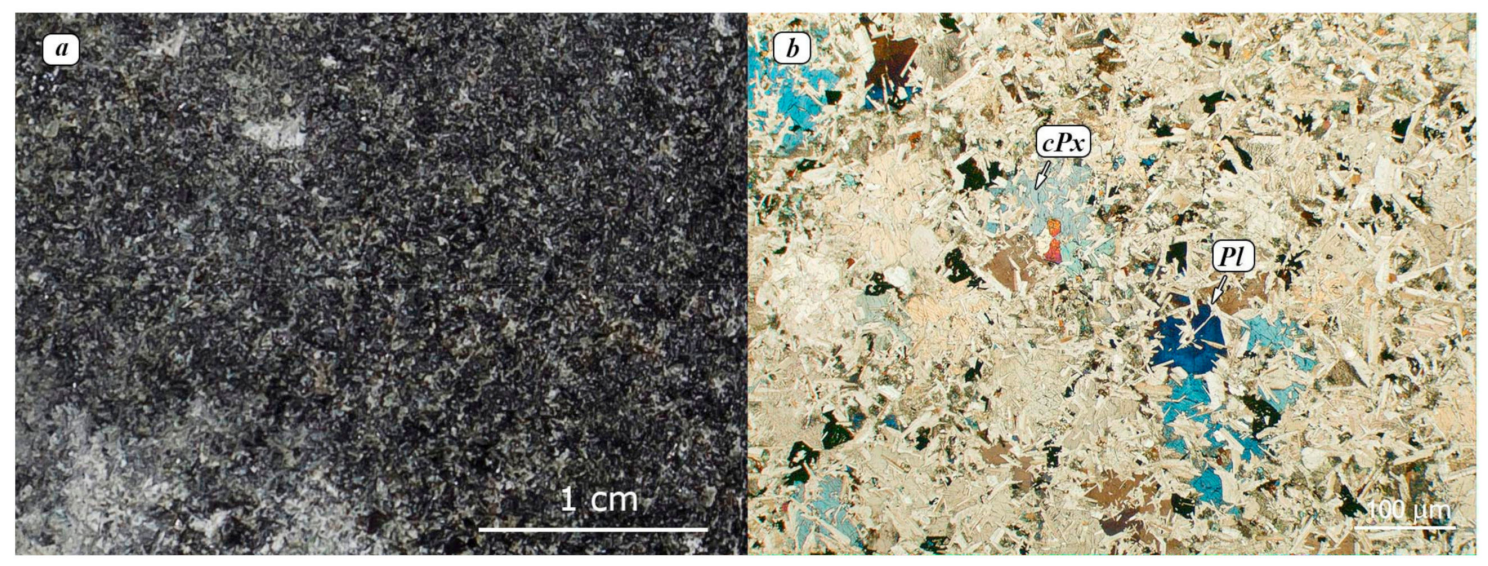

Figure 14. Photo (a) and photomicrorgaph (b) of gabbro-dolerite DL-1 ( $P l$-plagioclase, $c P x$-clynopyroxene).

The U-Pb system of Dl-1 zircons is highly homogeneous: the uranium and thorium content is moderately high: $1700-3700$ and $1100-4700 \mathrm{ppm}$, respectively, the radiogenic ${ }^{206} \mathrm{~Pb}$ content is 40-130 ppm, and a Th/U ratio (0.9-1.7) is typically magmatic. A concordant cluster of $8 \mathrm{U}-\mathrm{Pb}$ analyses corresponds to the age of $249.07 \pm 0.92 \mathrm{Ma}$ with an MSWD value of 0.2 and a probability of concordance at 0.7 (Figure 16). The weighted average age calculated on the ${ }^{206} \mathrm{~Pb} /{ }^{238} \mathrm{U}$ ratio for two analyzed baddeleyite grains corresponds to $250.8 \pm 6.9 \mathrm{Ma}$. Within error limits, it coincides with the age obtained from zircons, but baddeleyite is characterized by an almost complete absence of thorium and moderate uranium of 100-120 ppm, whereas radiogenic ${ }^{206} \mathrm{~Pb}$ does not exceed 3-4 ppm, which does not allow measuring the $\mathrm{U} / \mathrm{Pb}$ ratio with an accuracy comparable to zircon $(1 \sigma>3 \%-4 \%)$. 

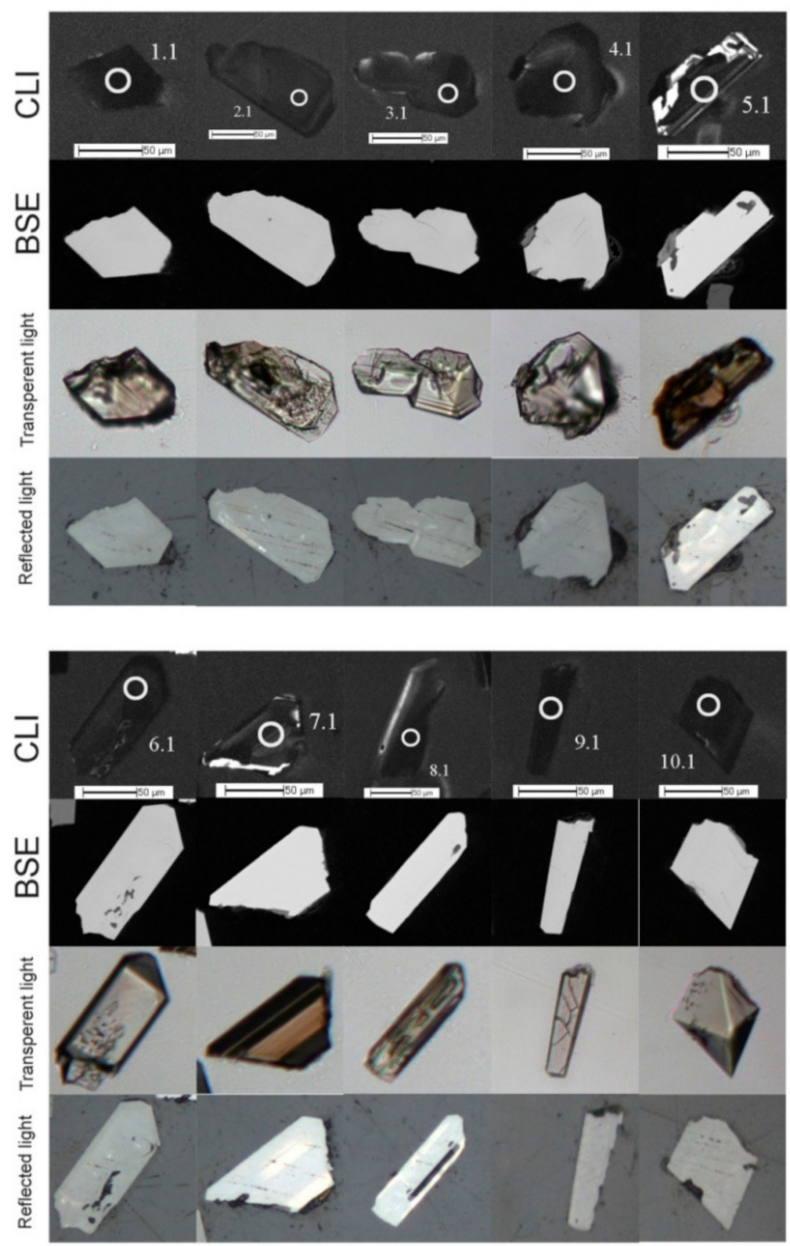

Figure 15. Zircon (1-4 and 9-10) and baddeleyite (5-8) grains from the gabbro-dolerite of the Daldykan intrusion (sample Dl-1).

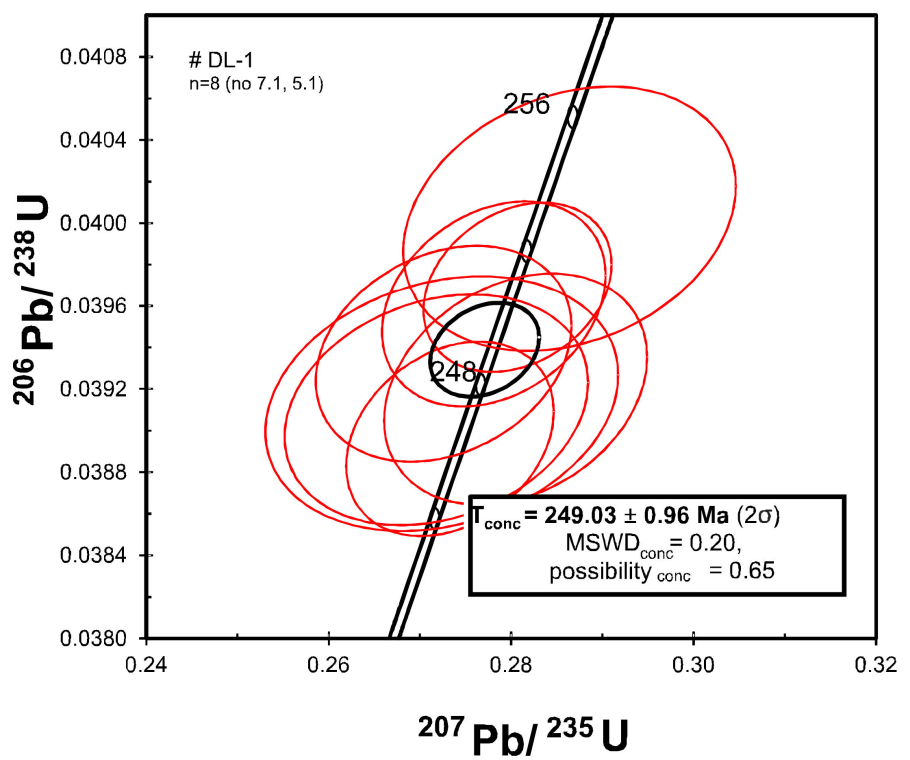

Figure 16. The U-Pb diagram with Concordia for zircon from the gabbro-dolerite Dl-1. Reported ellipses correspond to a $95 \%$ level of confidence of analytical data. 


\subsection{Radiogenic Isotopes}

The isotopic composition of $\mathrm{Sr}, \mathrm{Nd}$ and $\mathrm{Pb}$ and of the Re-Os isotope system for the whole-rock samples that the dated baddeleyites and zircons were extracted from are shown in Tables 2 and 3. As expected, trachydolerite (BT-1/114.6) of the supposed Ergalakh intrusion is more than 4-fold enriched in incompatible $\mathrm{REE}, \mathrm{Rb}$ and $\mathrm{Sr}$, compared to the subalkaline gabbro-dolerites of the Norilsk and Daldykan complexes. The measured ratios of $\mathrm{Nd}$ and $\mathrm{Pb}$ isotopes of the alleged Ergalakh intrusion are less radiogenic, while $\mathrm{Sr}$ is the most radiogenic, with ${ }^{87} \mathrm{Sr} /{ }^{86} \mathrm{Sr}$ up to 0.708 , and very similar to those published for the mafic rocks of the Norilsk region [14-16]. At the same time, the trachydolerite is characterized by the highest Re and the lowest Os contents, and the most radiogenic measured ${ }^{187} \mathrm{Os} /{ }^{188}$ Os value (Table 3).

Table 2. $\mathrm{Sr}-\mathrm{Nd}-\mathrm{Pb}$ isotope data for Turumakit intrusions (element contents in ppm, uncertainties correspond to the last digits of respective ratios).

\begin{tabular}{cccccccccccc}
\hline Sample & $\mathbf{R b}$ & $\mathbf{S r}$ & ${ }^{87} \mathbf{R b} /{ }^{\mathbf{6}} \mathbf{S r}$ & ${ }^{87} \mathbf{S r} /{ }^{86} \mathbf{S r} \pm \mathbf{2 \sigma}$ & $\mathbf{S m}$ & $\mathbf{N d}$ & ${ }^{147} \mathbf{S m} /{ }^{44} \mathbf{N d}$ & ${ }^{143} \mathbf{N d} /{ }^{144} \mathbf{N d} \pm \mathbf{2 \sigma}$ & ${ }^{206} \mathbf{P b} /{ }^{204} \mathbf{P b} \pm \mathbf{2 \sigma}$ & ${ }^{207} \mathbf{P b} /{ }^{204} \mathbf{P b} \pm \mathbf{2 \sigma}$ & ${ }^{208} \mathbf{P b} /{ }^{204} \mathbf{P b} \pm \mathbf{2 \sigma}$ \\
\hline DL-1 & 14.5 & 219 & 0.19170 & $0.705775 \pm 7$ & 4.81 & 16.9 & 0.17206 & $0.512744 \pm 3$ & $18.8406 \pm 5$ & $15.5896 \pm 4$ \\
5T-1/114.6 & 47.0 & 938 & 0.14481 & $0.708095 \pm 10$ & 16.4 & 76.8 & 0.12887 & $0.512334 \pm 2$ & $18.2812 \pm 10$ & $38.4779 \pm 13$ \\
5T-6/169.2 & 4.90 & 168 & 0.08439 & $0.705271 \pm 7$ & 1.84 & 6.60 & 0.16818 & $0.512661 \pm 3$ & $18.5325 \pm 7$ & $15.5356 \pm 9$ \\
5T-8/219.1 & 13.6 & 494 & 0.07955 & $0.707337 \pm 7$ & 3.44 & 12.2 & 0.17016 & $0.512599 \pm 3$ & $18.8393 \pm 10$ & $15.6203 \pm 6$ & $38.2412 \pm 28$ \\
\hline
\end{tabular}

Table 3. Re-Os isotope data for the Turumakit samples.

\begin{tabular}{cccccc}
\hline Sample & Re, ppb & Os, ppb & ${ }^{\mathbf{1 8 7}} \mathbf{R e} /{ }^{\mathbf{1 8 8}} \mathbf{O s}$ & ${ }^{\mathbf{1 8 7}} \mathbf{O s} /{ }^{\mathbf{1 8 8}} \mathbf{O s} \pm \mathbf{2 \sigma}$ & Model Age, Ma \\
\hline DL-1 & 0.146 & 0.106 & 6.754 & $0.1911 \pm 13$ & 597 \\
BT-1/114.6 & 1.468 & 0.034 & 263.0 & $1.2833 \pm 44$ & 264 \\
BT-8/219.1 & 0.649 & 0.336 & 9.333 & $0.2361 \pm 6$ & 725 \\
BT-8/121.9 & 1.006 & 0.052 & 97.93 & $0.6069 \pm 5$ & 294 \\
\hline
\end{tabular}

All three analyzed samples from the Norilsk and Ergalakh intrusions lie on the same correlation line within the ${ }^{187} \mathrm{Re} /{ }^{188} \mathrm{Os}-{ }^{187} \mathrm{Os} /{ }^{188} \mathrm{Os}$ diagram (not shown), corresponding to an age of $250 \pm 15 \mathrm{Ma}$ and an initial ${ }^{187} \mathrm{Os} /{ }^{188} \mathrm{Os}$ isotope ratio of $0.197 \pm 0.017$, whereas, the Daldykan gabbro-dolerite has a lower measured value of this ratio $\sim 0.1911$. The two-point isochron on the Norilsk intrusive gabbro-dolerites determines a very precise age estimation of $250.64 \pm 0.68 \mathrm{Ma}$ and an initial ratio of $0.19709 \pm 0.00075$ (also not shown). This value is rather higher than those for the model primitive upper mantle reservoir (0.1296 [21]) or convective mantle [22], as well as for any meteorite groups [23]. This may be a sign of the formation of such a lithospheric mantle due to the involvement of a radiogenic metasomatic substance, or mixing with crustal rocks of various composition and age [24]. If so, the least contaminated and the most primitive magmas are associated with the Daldykan intrusion, which is characterized by $\gamma_{O s}[25]$ of +30 , while the other studied samples from the Norilsk and alleged Ergalakh intrusions have $\gamma_{O s}$ within +48 to +58 . The model ages calculated relative to the isotope composition of the chondritic mantle [26] vary from 264 (for the alleged Ergalakh) up to $700 \mathrm{Ma}$ (for the Norilsk intrusion), and these reflect participation in the melting ancient crustal material as well. The intriguing fact is the earlier determined initial ${ }^{187} \mathrm{Os} /{ }^{188} \mathrm{Os}$ composition for the mafic and ultramafic rocks of the Norilsk, Talnakh and Kharaelakh intrusions was about 0.133 , and the $\gamma_{\mathrm{Os}}$ signature was within the interval from +4 to $+11[27,28]$.

Comparison of the initial isotope characteristics of various intrusive complexes of the Norilsk region (for example, the $\varepsilon \mathrm{Nd}-\varepsilon S \mathrm{Sr}$ diagram in Figure 17) shows that the rocks of the Norilsk complex (Talnakh, Norilsk 1 and Kharaelakh massifs) are characterized by a rather large range of $\varepsilon S r$, but fairly consistent values of $\varepsilon \mathrm{Nd}$. Our Turumakit intrusion data is almost at the center of this area, while the data for the Daldykan complex are identical to those given by Hawkesworth et al. [16].

At the same time, the studied rock of the Ergalakh complex is significantly different from the trachydolerites of the Turumakit region that we studied in both parameters. Firstly, negative $\varepsilon \mathrm{Nd}$ values are characteristic of alleged Ergalakh trachydolerite, which are close to those for the Lower 
Talnakh intrusive type of rocks (Lower Talnakh and Lower Norilsk intrusions). Secondly, they are distinguished by high values of $\varepsilon S r$. Thus, our data (large green triangle) are located far from those for typical Ergalakh rocks (small green triangles), which indicates their different genesis.

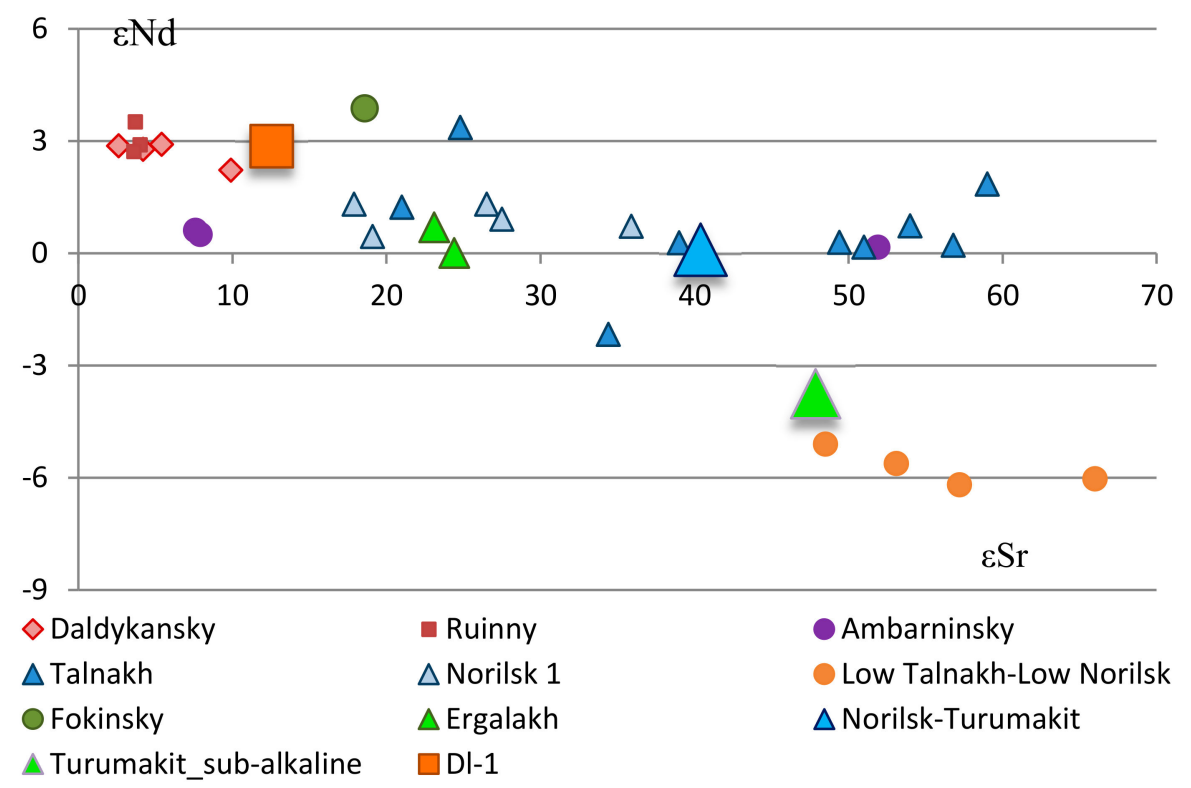

Figure 17. $\varepsilon N d-\varepsilon S r$ diagram for intrusive rocks of the Norilsk region (data are from [16] and unpublished authors' data, large symbols, studied Turumakit samples: BT-6/169.2; Norilsk-Turumakit, BT-1/114.6; supposed Ergalakh, Dl-1-Daldykan).

\section{Discussion}

The problem of classification and age estimation for intrusions from the Norilsk region and their correlation with volcanic rocks has a very long story. Due to the absence of geological relationships between intrusions and lavas, geochemical and isotopic methods have a great importance. The first results of an ore-bearing intrusion isotope dating by the K-Ar method during 1970th-1980th demonstrated a huge range of values $[29,30]$ due to the secondary alteration of rocks and the low accuracy of the analysis. U-Pb zircon age for the Norilsk 1 intrusions of $248 \pm 3.8$ Ma was only obtained in 1992 [31], as well as the recalculated age of $250 \pm 1.5 \mathrm{Ma}$ for the inception of Siberian Traps flood volcanism [32]. Later on, a very precise ${ }^{39} \mathrm{Ar}-{ }^{40} \mathrm{Ar}$ age was obtained for biotite and hornblende from the Norilsk 1 intrusion [33]: $250 \pm 1.5$ and $249 \pm 1.6 \mathrm{Ma}$, respectively, which is a reasonable age of magma crystallization, since biotite igneous mineral in the studied biotite-olivine gabbro-dolerites.

The development of local analytical methods (SIMS and laser ablation with ICP-MS) was the trigger for study of accessory minerals, especially zircons and baddeleyites, from Norilsk rocks. Malitch with co-authors studied zircons and baddeleyites from the Kharaelakh and Norilsk 1 intrusions, and several other massifs [34-36], and obtained different ages for individual intrusions which were interpreted as different stages of intrusion formation. So, for the Kharaelakh intrusion, two ages of $347 \pm 16$ and $235.7 \pm 6.1$ Ma were attributed to two events of tectonic activity within the Siberian Craton. Additionally, for the Norilsk 1 intrusion, four events were identified according to four age groups of zircon and baddeleyite: $290 \pm 2.8,261.3 \pm 1.6,245.7 \pm 1.1,236.5 \pm 1.8$ and $226.7 \pm 0.9 \mathrm{Ma}$, which the authors interpreted as successive stages of crystallization. But which specific events are characterized by these ages remains unclear, since crystallization of the Norilsk intrusions being the subvolcanic bodies occurred for a very short time. This is confirmed by the texture of dolerite rocks, the glass appearance in the contact zones of intrusions and melts inclusions in rock-forming minerals, the zoning of rock-forming minerals [37], and the paleomagnetic data. That is, the process of magma crystallization took a short time, and it could not correlate with the four zircon stages mentioned above. 
Moreover, the Hf isotopic composition of the studied zircon and baddeleyite indicates the complex nature of the magmatic source of the Norilsk intrusions, i.e., juvenile and lithospheric mantle and continental crust. Thus, the appearance of the inherited (captured) zircon of various ages is associated just with the participation in the melting of the material of the continental crust and metamorphic rocks of different ages.

\subsection{Geochemical Constrains}

\subsubsection{Major Components}

The studied gabbro-dolerites of the Norilsk intrusions of the Turumakit area are well compared with the intrusions of the Talnakh and Norilsk ore junctions $[38,39]$. Their geochemical features are very similar (Figure 6), but there are some differences in their differentiation. The Norilsk intrusions located in the Turumakit do not contain high-magnesian rocks, which are observed in the Talnakh and Norilsk intrusions, and are an indispensable attribute of ore-bearing bodies. Thus, the MgO content in studied samples in the Turumakit intrusions does not exceed $18 \mathrm{wt} \%$ (Figure 6), whereas picritic gabbro-dolerites in economically significant intrusions are characterized by $25-27 \mathrm{wt} \%$ [29,38]. Given the relatively low $\mathrm{MgO}$ content, they were designated as picrite-like rocks. The second important feature of intrusive bodies in the Turumakit region is the limited amount of taxitic gabbro-dolerites in comparison with classic ore-bearing intrusions. The sulfide content in the rocks is lower as well (usually, $3 \mathrm{vol} \%$ ).

Any attempt at classification of subalkaline rocks of the Norilsk district is difficult realize. In the Norilsk district, these rocks have been designated as two intrusive complexes, Ergalakh and Avamsky [4], represented by sills and dikes, respectively. The trachydolerite sills of the Ergalakh complex in the Norilsk area are compared with the rocks of the Ivakinsky formation, which has a subalkaline composition and takes the lowest position in the tuff-lava sequences in the Norilsk district [32].

There were identified two sub-complexes of the Ergalakh complex, namely: alkaline rocks correlated with the lower part of the Ivakinsky formation (Er I), and subalkaline rocks close to rocks of the upper part of this formation (Er II). Indeed, there are two types of intrusive rocks in the Norilsk district differing in titanium and alkali contents: high- $\mathrm{Ti}\left(\mathrm{TiO}_{2}>3 \%\right)$ and low $\mathrm{Ti}\left(\mathrm{TiO}_{2} 2.2-2.5, \mathrm{~K}_{2} \mathrm{O}<5.0 \%\right)$.

However, both types of these rocks fall in the area of subalkaline basalts in the diagram $\mathrm{SiO}_{2} \mathrm{vs}$ $\mathrm{Na}_{2} \mathrm{O}+\mathrm{K}_{2} \mathrm{O}$, similar to the rocks of the Ivakinsky formation [15-17,29-31].

Hawkesworth and co-authors [16] studied the rock of the Ergalakh complex in the northern and central parts of the Norilsk district, and subdivided them into two groups as well: low $\mathrm{Ti}(2.2 \mathrm{wt} \%$ $\mathrm{TiO}_{2}$ ) and high-Ti $\left(3 \mathrm{wt} \%-3.3 \mathrm{wt} \% \mathrm{TiO}_{2}\right.$ ). The most representative data on the rocks of the Ergalakh complex were obtained by Ryabov (Figure 6), who studied them in different parts of the Norilsk district (including the Turumakit area), and within the Syverma plateau [17]. His data demonstrate that the $\mathrm{TiO}_{2}$ content in these rocks varies between $2.5 \mathrm{wt} \%-3.6 \mathrm{wt} \%$ forming a continuous range of compositions. Our data on the rocks of the Turumakit area (Tables 1 and 2) occupy a special place in the $\mathrm{TiO}_{2}-\mathrm{SiO}_{2}$ diagram and show the elevated silica and high titanium concentration in several samples, which compositions correspond to subalkaline rocks. The trachybasalts of the Ivakinsky formation are similar to the low-Ti varieties of the Ergalakh complex, but differ in higher silica concentrations in some cases.

Data on the Avamsky complex is mostly obtained from the dikes of the Maymecha-Kotuy region (Figure 18), and only one sample from the Norilsk district was analyzed [38]. The rocks of the Avamsky complex are considered in the last work [38] as intermediate in composition between Er I and Er II, but they are closer to the second type of the Ergalakh complex. 


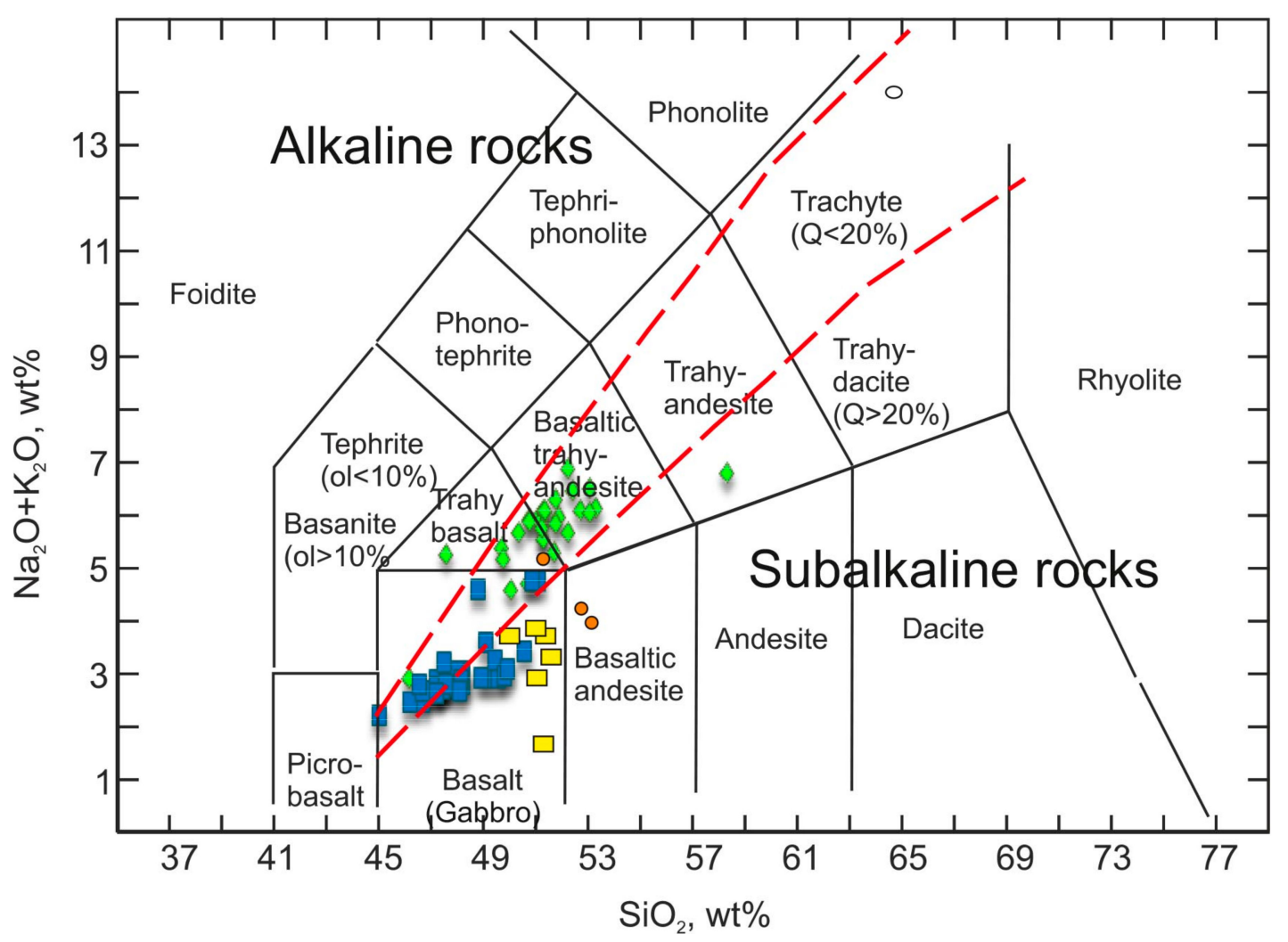

Figure 18. Comparative diagram of $\mathrm{SiO}_{2}$ vs $\mathrm{Na}_{2} \mathrm{O}+\mathrm{K}_{2} \mathrm{O}$ for various intrusive complexes of the Norilsk district. Data for the Ergalakh (green diamonds) and Norilsk (blue squares) rocks are given in Table S1 and Table 1 (Turumakit area); data for Avamsky (yellow squares) complex after [16], Ivakinsky Formation (orange circles) - unpublished authors' data. Red dashed lines are represented boundaries between alkaline and subalkaline rocks, according to [39].

Indeed, the titanium concentrations in these rocks are not different from those for the Ergalakh complex, but they contain much less alkalis (Figure 18). A sample of the Avamsky complex from the Norilsk region is not similar to samples of the Avamsky samples from the Maymecha-Kotuy district [16], since it more closely corresponds to alkaline rocks. Significant inconsistencies in the location of the dikes of this complex and their different composition lead to the question of the legality of referring them to a single complex, which requires further study.

\subsubsection{Trace Elements}

Unfortunately, there is very little information on rare elements in the samples of the Avamsky complex in comparison with the major elements. Thus, a more or less reliable spectrum was obtained only for one sample of the Avamsky complex taken in the Norilsk region [40]. The distribution of rare elements in the rocks of the Ergalakh and Avamsky complexes, as well as in subalkaline rocks of the Turumakit area, reveals a number of significant differences between them. First of all, the rocks of the Ergalakh and Avamsky (Figure 19) complexes are characterized by high uranium, which forms a small, positive anomaly of this element in patterns. This anomaly is absent in the Turumakit rocks (Figure 19). This is evidenced by the $\mathrm{U} / \mathrm{Nb}$ ratio, which is $2.2-4.0$ for the Eraglakh complex, and 1.2-1.6 for the subalkaline rocks of the Turumakit area. This ratio for the Ivakinsky formation is similar to the Ergalakh rocks. There is a difference between these two rock types in the $\mathrm{Gd} / \mathrm{Yb}$ ratio: it is higher for the Ergalakh complex (2.1-2.5) and lower for the Turumakit complex (1.8 and 1.9). The Avamsky complex is characterized by a very gentle inclination of the spectrum (Figure 19). 


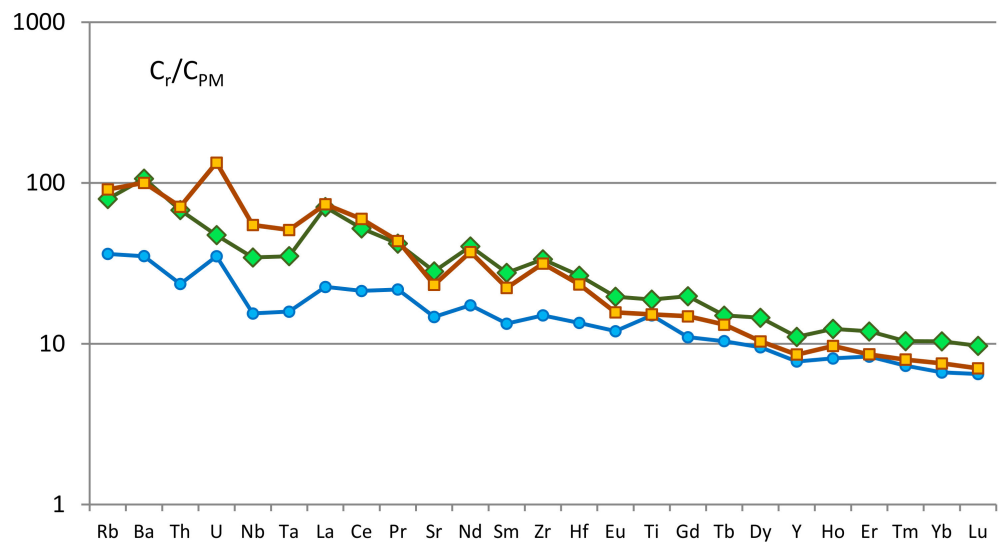

Figure 19. Normalized [19] trace-element patterns for sub-alkaline rocks of Avamsky (blue circles) and Ergalakh complexes of the Norilsk region (yellow squares, SG-9-2200 [16]) and the Turumakit area (green diamonds).

Thus, the subalkaline rocks of the Turumakit area indicate their difference from the typical Ergalakh complex. It is possible to suggest that this is a special type of the Ergalakh complex. The age of these rocks allows us to attribute their formation to the latest stage of magmatism evolution in the Norilsk district, whereas the age of typical rocks from the Ergalakh intrusions has never determined by modern geochemical methods.

\subsubsection{Radiogenic Isotopes}

A number of recent studies on various flood basalt provinces have suggested that the subcontinental lithosphere maybe a viable source for the basalts, because they display a wide range of $\mathrm{Nd}-\mathrm{Sr}-\mathrm{Pb}$ isotopic compositions [16,41-43].

In $\varepsilon S r-\varepsilon N d(t)$ space, all the Siberian mafic intrusive rocks define an array that lies near the mantle correlation line, but is distinctly displaced to the right (Figure 20). This relationship may be defined by a hyperbola having three different components: depleted sub-oceanic mantle, undepleted primitive mantle, and old continental crust.

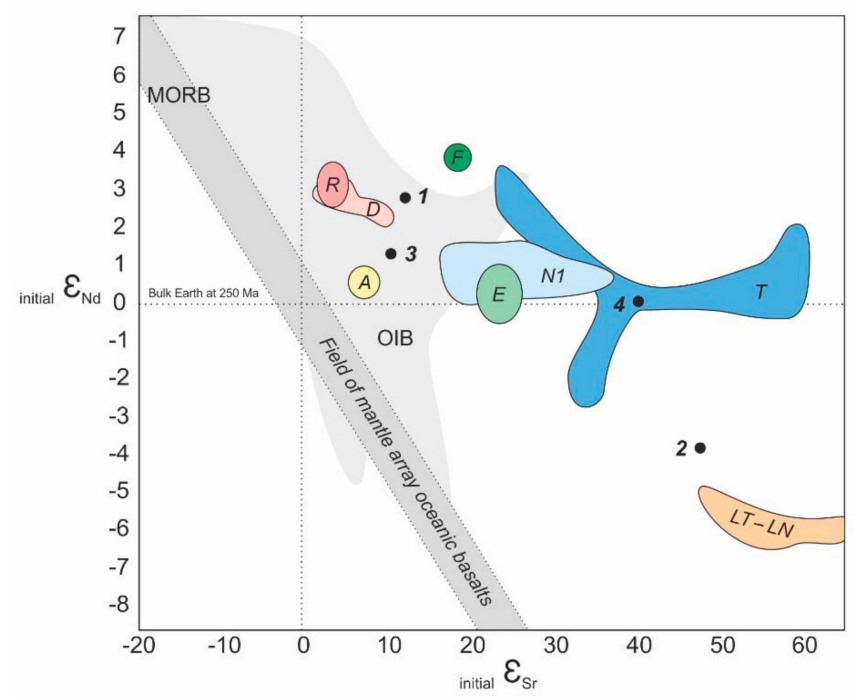

Figure 20. Initial $\varepsilon \mathrm{Nd}-\varepsilon S \mathrm{Sr}$ plot for the Siberian intrusive rocks. D-Daldykan, $\mathrm{R}-$ Ruinny, A-Ambarninsky, T-Talnakh, N1-Norilsk 1, LT-LN-Lower Talnakh-Lower Norilsk, F-Fokinskiy, E-Ergalakh from [16,44]. This work: 1-DL-1, 2-BT-6/114.6, 3-BT-6/169.2, 4-BT-8/219.1. Fields of Mid-Ocean Ridge Basalts (MORBs) and Ocean Island Basalts (OIBs) are from [45]. 
There is an excellent, overlapping correspondence in Figure 20 between the Norilsk type samples 1 and 3 and the basalts of the oceanic islands in terms of their $\mathrm{Nd}$ and Sr-isotopic signatures. This feature was also noted by [41,44], particularly in the case of the Columbia River Basalts, and in general, for all continental flood basalts by [46].

But the rocks of the alleged Ergalakh complex studied by the authors (2 in Figure 20) are located far from typical Ergalakh rocks (E in Figure 20), which indicates their different genesis, but under the strong influence of the continental crust, as well as the Lower Talnakh and Lower Norilsk weakly mineralized intrusions. The Re-Os isotopic data (Table 3) also confirm that the sub-alkaline rocks of the Turumakit area are only comparable to those of disseminated sulfide ores from weakly mineralized intrusives of the Norilsk district [26,28]. As mentioned above, the zircon and baddeleyite Hf isotopic composition also proves the participation of continental crust material in the magmatic source of the Norilsk intrusions [36].

\subsection{Geochronological Constrains}

As mentioned above, the age determination of magmatic rocks of the Norilsk region by isotopic methods began from the 1970s and continues to the present, and if the first decades geochronological dating was carried out exclusively by the potassium-argon method, then the main attention was focused on obtaining the most accurate age estimations of the injection and crystallization of various ore-bearing and barren igneous bodies and effusive trap basalts associated with the manifestation of the Siberian Permian-Triassic plume. The accuracy of modern $\mathrm{U}-\mathrm{Pb}$ isotope analysis allowed the limiting of the time of formation of Siberian traps within 252-255 Ma [31,33,47], while the time of injection of various intrusions varies from $10-15 \mathrm{Ma}$ from 260 to $240 \mathrm{Ma}[28,35,36]$. A recently published overview of detailed dating by the local U-Pb zircon method (SHRIMP-II) from 22 mafic intrusions of the Norilsk region [48] showed that the distribution of the obtained age estimations can be determined by two main magmatism pulses at $244 \pm 4$ and $254 \pm 4 \mathrm{Ma}$, with quasi-synchronous sulfide ore formation in these intrusions $245-250$ million years ago.

The results of the baddeleyite and zircon $\mathrm{U}-\mathrm{Pb}$ dating of the Turumakit region mafic intrusions are consistent with previously obtained estimations for the crystallization age of the Norilsk region intrusions [48]; moreover, these ages indicate that the studied intrusions belong to both recognized magmatic pulses: the Norilsk and Daldykan intrusions formed at an early one of $254 \pm 4 \mathrm{Ma}$, and if the Norilsk intrusion can be associated with the beginning of magmatic activity in the region $251.5 \pm 3.5 \mathrm{Ma}$, then the Daldykan intrusion was injected at the final magmatic activity of this pulse $249.03 \pm 0.9$ Ma. Moreover, it is obvious that the alleged Ergalakh intrusion was one of the last in the region $(244.8 \pm 2.7 \mathrm{Ma})$. Up to now there are a few ages characterizing the Ergalakh intrusion crystallization within the Norilsk region. However, all of them were determined by inherited Proterozoic zircons, so the true correlation with this intrusive event is impossible. Based on our data we suggest that the studied intrusive from the Turumakit region represents a distinct subalkaline trachydolerite intrusion during the final stages of the plume magmatic activity in the Siberian region.

\section{Conclusions}

(1) We have studied mafic rocks of the Turumakit area previously attributed to the three intrusive complexes-Norilsk, Daldykan of normal alkalinity and to the sub-alkaline rocks preliminary referred to the Ergalakh intrusive complex. The rocks from the first two units have geochemical features, typical of the Norilsk and Daldykan intrusions. Norilsk intrusions of the Turumakit area do not comprise high-Mg rocks similar to the picritic gabbro-dolerites in ore-bearing massifs, and contain low concentrations of sulfides (vol 3\%).

(2) The subalkaline rocks of the Turumakit area have a number of features that distinguish them from the typical Ergalakh rocks. They are represented by large bodies consisting of coarse varieties of rocks with pegmatite segregations while typical Ergalakh massifs are homogeneous with fine-grained texture. The sub-alkaline Turumakit rocks are enriched in titanium and silica (up to 
$5.5 \mathrm{wt} \% \mathrm{TiO}_{2}$, in comparison with the typical Ergalakh rocks, $2.2 \mathrm{wt} \%-3.3 \mathrm{wt} \% \mathrm{TiO}_{2}$ ). They are characterized by a low uranium content and $\mathrm{Gd} / \mathrm{Yb}$ ratio (1.6).

(3) The U-Pb system of zircon and baddeleyite of the studied samples from the three intrusions assumes sub-synchronous but nevertheless distinctly sequential formation: First, the gabbro-dolerites of the Norilsk intrusions crystallized at $250.3 \pm 1.4$ m.y. ago, then the Daldykan intrusive at $249.03 \pm 0.96$, and the last subalkaline trachydolerites of the alleged Ergalakh intrusion completed magmatism $-244 \pm 2.7$ m.y. ago.

(4) The initial isotope characteristics (at age $250 \mathrm{Ma}$ ) calculated for these rocks are follows: Norilsk intrusions $\varepsilon \mathrm{Nd}=+0.1 \sim+1.4, \varepsilon \mathrm{Sr}=+10 \sim+40, \gamma_{\mathrm{Os}}=+48-58,{ }^{206} \mathrm{~Pb} /{ }^{204} \mathrm{~Pb} 18.17-18.20,{ }^{207} \mathrm{~Pb} /{ }^{204} \mathrm{~Pb}$ 15.56-15.59, ${ }^{208} \mathrm{~Pb} /{ }^{204} \mathrm{~Pb} 38.11-38.16$; the Daldykan complex $\varepsilon \mathrm{Nd}=+2.9, \varepsilon \mathrm{Sr}=+12.5, \gamma_{\mathrm{Os}}=+30$, ${ }^{206} \mathrm{~Pb} /{ }^{204} \mathrm{~Pb}$ 18.57, ${ }^{207} \mathrm{~Pb} /{ }^{204} \mathrm{~Pb} 15.57,{ }^{208} \mathrm{~Pb} /{ }^{204} \mathrm{~Pb} 38.22$; Turumakit trachydolerite $\varepsilon \mathrm{Nd}=-3.8$, $\varepsilon S \mathrm{r}=+47.9, \gamma_{\mathrm{Os}}=+40,{ }^{206} \mathrm{~Pb} /{ }^{204} \mathrm{~Pb} 17.88,{ }^{207} \mathrm{~Pb} /{ }^{204} \mathrm{~Pb} 15.51,{ }^{208} \mathrm{~Pb} /{ }^{204} \mathrm{~Pb} 37.78$. The first two correlate well with the data published for the rocks from a type locality within the Norilsk district (Norilsk and Daldykan), while the Turumakit trachydolerite, alleged to be Ergalakh, is a completely another case.

Supplementary Materials: The following are available online at http://www.mdpi.com/2075-163X/10/2/165/s1, Table S1: Bulk compositions of igneous rocks within the Turumakit area

Author Contributions: Conceptualization and writing were carried out by E.S. and N.K; the methodology and interpretation of isotopic data by E.S. and B.B.; and the field trip sampling was done by N.K. All authors have read and agreed to the published version of the manuscript.

Funding: This work was done as a part of CIR 'VSEGEI" works under the project of the Russian State Geological Survey No. 049-00009-1800, aimed in the development of laboratory and analytical methods, and was supported by Russian Foundation for Basic Researches (project 18-05-70094).

Acknowledgments: The authors are grateful to K. Shishaev (Norilskgeologiya LLC) and E. Krasnova for a fruitful discussion of the Turumakit area geology and isotopic data. We are very grateful to an unknown reviewer who made an invaluable contribution, not only to clarifying the text of our article, but also significantly to improving the English language.

Conflicts of Interest: The authors declare no conflict of interest.

\section{References}

1. Urvantsev, N.N. North Siberian Ni-bearing area. Geol. Geophys. 1974, 3, 3-11. (In Russian)

2. Dyuzhikov, O.A.; Distler, V.V.; Strunin, B.M.; Mkrtychyan, A.K.; Sherman, M.L.; Sluzhenikin, S.F.; Lurye, A.M. Geology and Ore Potential of the Noril'sk Ore District; Nauka: Moscow, Russia, 1988; p. 238. (In Russian)

3. Sherman, M.L. GeologicalMap of the Noril'sk Ore Dstrict, 1:200000 Scale; VSEGEI: Leningrad, Russia, 1991.

4. Lyul'ko, V.A. Legend for 1: 50000 Scale Map, Noril'sk Group; Geoinformmark: Moscow, Russia, 1993 ; p. 53. (In Russian)

5. Soderlund, U.; Johansson, L. A simple way to extract baddeleyite $\left(\mathrm{ZrO}_{2}\right)$. Geochem. Geophys. Geosyst. 2002, 3, 1-7. [CrossRef]

6. Williams, I.S. U-Th-Pb Geochronology by Ion Microprobe. Rev. Econ. Geol. 1998, 7, 1-35.

7. Rodionov, N.V.; Belyatsky, B.V.; Antonov, A.V.; Kapitonov, I.N.; Sergeev, S.A. Comparative in-situ U-Th-Pb geochronology and trace element composition of baddeleyite and low-U zircon from carbonatites of the Palaeozoic Kovdor alkaline-ultramafic complex, Kola Peninsula, Russia. Gondwana Res. 2012, 21, 728-744. [CrossRef]

8. Ludwig, K.R. SQUID 1.02, A User Manual, A Geochronological Toolkit for Microsoft Excel; Berkeley Geochronology Center Special Publication: Berkeley, CA, USA, 2001.

9. Wetherill, G.W. Discordant uranium-lead ages. Trans. Am. Geophys. Union 1956, 37, 320-326. [CrossRef]

10. Ludwig, K.R. User's Manual for Isoplot/Ex, Version 3.00. A Geochronological Toolkit for Microsoft Excel; Berkeley Geochronology Center Special Publication: Berkeley, CA, USA, 2003.

11. Stacey, J.S.; Kramers, J.D. Approximation of terrestrial lead isotope evolution by a two-stage model. Earth Planet. Sci. Lett. 1975, 26, 207-221. [CrossRef] 
12. Krivolutskaya, N.A.; Belyatsky, B.V.; Smolkin, V.F.; Mamontov, V.P.; Fanygin, A.S.; Svirskaya, N.M. Geochemical specific of massifs of the Druzite Complex in Central Belomorian Mobil Belt: II Sm-Ndisotopic system of the rocks and U-Pb system of zircons. Geochem. Int. 2010, 48, 1064-1083. [CrossRef]

13. Zolotukhin, V.V.; Vilensky, A.M.; Dyuzhikov, O.A. Basalts of the Siberian Platform; Nauka: Novosibirsk, Russia, 1986; p. 245. (In Russian)

14. Lightfoot, P.C.; Naldrett, A.J.; Gorbachev, N.S.; Doherty, W.; Fedorenko, V.A. Geochemistry of the Siberian traps of the Noril'sk area: with implications for the relative contributions of crust and mantle to flood basalts. Contrib. Mineral. Petrol. 1990, 104, 631-644. [CrossRef]

15. Wooden, J.L.; Czamanske, G.K.; Bouse, R.M.; King, B.-S.W.; Knight, R.J.; Siems, D.F. Isotopic and trace-element constraints on mantle and crustal contributions to Siberian continental flood basalts, Norilsk area, Siberia. Geochim. Cosmochim. Acta 1993, 57, 3677-3704. [CrossRef]

16. Hawkesworth, C.J.; Lightfoot, P.C.; Fedorenko, V.A.; Blake, S.; Naldrett, A.J.; Doherty, W.; Gorbachev, N.S. Magma differentiation and mineralisation in the Siberian flood basalts. Lithos 1995, 34, 61-88. [CrossRef]

17. Ryabov, V.V.; Shevko, A.Y.; Gora, M.P. Trap Magmatism and Ore Formation in the Siberian Noril'sk Region; Springer: Amsterdam, The Netherlands, 2014; Volume 1, p. 2.

18. Rogers, C.; Cousens, B.; Ernst, R.E.; Söderlund, U. Phosphorus and Potassium Metasomatic Enrichment in the Mantle Source of the c. 1450-1425 Michael-Shabogamo Gabbro of Eastern Laurentia. J. Petrol. 2019, 60, 57-83. [CrossRef]

19. Hofmann, A.W. Chemical differentiation of the earth: the relationship between mantle, continental and ocean crust. Earth Planet Sci. Lett. 1988, 90, 297-314. [CrossRef]

20. Gervasoni, F.; Klemme, S.; Rohrbach, A.; Tobias Grützner, T.; Berndt, J. Experimental constraints on the stability of baddeleyite and zircon in carbonate- and silicate-carbonate melts. Am. Mineral. 2017, 102, 860-866. [CrossRef]

21. Meisel, T.; Walker, R.J.; Irving, A.J.; Lorand, J.P. Osmium isotopic compositions of mantle xenoliths: a global perspective. Geochim. Cosmochim. Acta 2001, 65, 1311-1323. [CrossRef]

22. Rudnick, R.; Walker, R.J. Interpreting ages from Re-Os isotopes in peridotites. Lithos 2009, 112S, $1083-1095$. [CrossRef]

23. Day, J.M.D.; Brandon, A.D.; Walker, R.J. Highly siderophile elements in Earth, Mars, the Moon, and asteroids. Rev. Mineral. Geochem. 2017, 81, 161-238. [CrossRef]

24. Reisberg, L.; Lorand, J.-P.; Bedini, R.M. Reliability of Os model ages in pervasively metasomatazed continental mantle lithosphere: a casee study of Sidamo spinel peridotute xenoliths (East African Rift, Ethiopia). Chem. Geol. 2004, 208, 119-140. [CrossRef]

25. Chen, J.H.; Papanastassiou, D.A.; Wasserburg, G.J. Re-Os systematics in chondrites and the fractionation of the platinum group elements in the early solar system. Geochim. Cosmochim. Acta 1998, 62, 3379-3392. [CrossRef]

26. Walker, R.J.; Morgan, J.W.; Horan, M.F.; Czamanske, G.K.; Krogstad, E.J.; Fedorenko, V.A.; Kunilov, E. $\mathrm{Re}-\mathrm{Os}$ isotopic evidence for an enriched-mantle source for the Noril'sk-type, ore-bearing intrusions. Geochim. Cosmochim. Acta 1994, 58, 4179-4197. [CrossRef]

27. Shirey, S.B.; Walker, R.J. The Re-Os isotopes in cosmochemistry and high-temperature geochemistry. Annu. Rev. Earth Planet. Sci. 1998, 26, 423-500. [CrossRef]

28. Malitch, K.N.; Latypov, R.M. Re-Os and S isotope contrants on timing and source heterogeneity of PGE-Cu-Ni sulfide ores: a case study at the Talnakh ore junction, Noril'sk province, Russia. Can. Miberalogist 2011, 49, 1653-1677. [CrossRef]

29. Dodin, D.A.; Batuev, B.N. Geology and petrology of the Talhakh differentiated intrusions and their metamorphic aureole. In Petrology and Ore Resource Potential of the Talnakh and Noril'sk Differentiated Intrusions; Nedra: Leningrad, Russia, 1971; pp. 31-100. (In Russian)

30. Zolotukhin, V.V.; Vilensky, A.M.; Vasil'ev, Y.R. Magnesium Basic Rocks of Western Part of the Siberian Platform and Problems of Nickel Potential; Nauka: Novosibirsk, Russia, 1984; p. 208. (In Russian)

31. Campbell, I.H.; Czamanske, G.K.; Fedorenko, V.A.; Hill, R.I.; Stepanov, V. Synchronism of the Siberan Traps and Permian-Triassic boundary. Science 1992, 258, 1760-1763. [CrossRef] [PubMed]

32. Renne, P.R.; Basu, A.R. Rapid eruption of the Siberian Trap flood basalts at the Permian-Triassic boundary. Science 1991, 253, 176-179. [CrossRef] [PubMed] 
33. Renne, P.R. Excess 40Ar in biotite and hornblende from the Noril'sk 1 intrusion, Siberia: implication for the age of the Siberan Traps. Earth Planet. Sci. Lett. 1995, 131, 165-176. [CrossRef]

34. Malitch, K.N.; Badanina, I.Y.; Belousova, E.A.; Tuganova, E.V. Results of U-Pb dating of zircon and baddeleyite from the Norilsk-1 ultramafic-mafic intrusion (Russia). Russ. Geol. Geophys. 2012, 53, 123-130. [CrossRef]

35. Malitch, K.N.; Belousova, E.A.; Griffin, W.L.; Badanina, I.Y.; Pearson, N.J.; Presnyakov, S.L.; Tuganova, E.V. Magmatic evolution of the ultramafic-mafic Kharaelakh intrusion (Siberian Craton, Russia): Insight from trace-element, U-Pb and Hf isotope data on zircon. Contrib. Mineral. Petrol. 2010, 159, 753-768. [CrossRef]

36. Malitch, K.N.; Belousova, E.A.; Griffin, W.L.; Badanina, I.Y.; Latypov, R.M.; Sluzhenikin, S.F. New insights on the origin of ultramafic-mafic intrusions and associated Ni-Cu-PGE sulfide deposits of the Noril'sk and Taimyr provinces, Russia: evidence from radiogenic and stable isotope data. In Processes and Ore Deposits of Ultramafic-Mafic Magmas through Space and Time; Elsevier: Amsterdam, The Netherlands, 2017; Volume 7, pp. 198-237.

37. Krivolutskaya, N.A. Siberian Traps and Pt-Cu-Ni Deposits of the Norilsk Area; Springer: Amsterdam, The Netherlands, 2016; p. 316.

38. Lul'ko, V.A.; Fedorenko, V.A.; Distler, V.V.; Sluzhenikin, S.F.; Kunilov, V.E.; Stekhin, A.I.; Ryabikin, V.A.; Simonov, O.N.; Zen'ko, T.E. Geology and Ore Deposits of the Noril'sk Region; Guidebook VII IPS: Moscow/Noril'sk, Russia, 1994; p. 67.

39. Streckeisen, A.; Zanettin, B.; Le Bas, M.J.; Bonin, B.; Bateman, P.; Bellieni, G.; Dudek, A.; Efremova, S.; Keller, J. Igneous Rocks. A Classification and Glossary of Terms; Le Maitre, R.W., Ed.; Cambridge University Press: Cambridge, UK, 2002; p. 37.

40. Krivolutskaya, N.A.; Rudakova, A.V. Structure and Geochemistry of trap rocks from the Noril'sk trough, Northwestern Siberian Craton. Geochem. Int. 2009, 47, 635-656. [CrossRef]

41. Carlson, R.W.; Lugmair, G.W.; McDougall, J.D. Columbia River volcanism: the question of mantle heterogeneityor crustal contamination. Geochim. Cosmochim. Acta 1981, 45, 2483-2500. [CrossRef]

42. Allegre, C.J.; Dupre, B.; Richard, P.; Rousseau, D. Subcontinental versus suboceanic mantle debate, II. $\mathrm{Nd}-\mathrm{Sr}-\mathrm{Pb}$ isotopic comparison of continental tholeiites with mid-ocean ridge tholeiites, and the structure of the continental lithosphere. Earth Planet. Sci. Lett. 1982, 57, 25-34. [CrossRef]

43. Carlson, R.W.; Lugmair, G.W.; McDougall, J.D. Columbia River volcanism: the question of mantle heterogeneity or crustal contamination (reply to a comment by DePaolo, D.J.). Geochim. Cosmochim. Acta 1983, 47, 845-846. [CrossRef]

44. Sharma, M.; Basu, A.; Nesterenko, G.V. Temporal Sr-, Nd- and Pb-isotopic variations in the Siberian flood basalts: implications for the plume-source characteristics. Earth Planet. Sci. Lett. 1992, 113, 365-381. [CrossRef]

45. Hart, S.R.; Staudigel, H. Isotopic characterization and identification of recycled components. In Crust-Mantle Recycling at Convergence Zones; Hart, S.R., Gullen, L., Eds.; Kluwer Academic Publishers: Berlin, Germany, 1989; pp. 15-28.

46. McDougall, J.D. Continental flood basalts and MORB: A brief discussion of similarities and differences in their petrogenesis. In Continental Flood Basalts; McDougall, J.D., Ed.; Kluwer Academic Publishers: Berlin, Germany, 1988; pp. 331-341.

47. Dalrymple, G.B.; Czamanske, G.K.; Fedorenko, V.A.; Simonov, O.N.; Lanphere, M.A.; Likhachev, A.P. A reconnaissance $40 \mathrm{Ar} / 39 \mathrm{Ar}$ geochronologic study of ore-bearing and related rocks, Siberian Russia. Geochim. Cosmochim. Acta 1995, 59, 2071-2083. [CrossRef]

48. Prasolov, E.M.; Sergeev, S.A.; Belyatsky, B.V.; Bogomolov, E.S.; Gruzdov, K.A.; Kapitonov, I.N.; Krymsky, R.S.; Khalenev, V.O. Isotopic systematics of $\mathrm{He}, \mathrm{Ar}, \mathrm{S}, \mathrm{Cu}, \mathrm{Re}, \mathrm{Os}, \mathrm{Pb}, \mathrm{U}, \mathrm{Sm}, \mathrm{Nd}, \mathrm{Rb}, \mathrm{Sr}, \mathrm{Lu}$, and $\mathrm{Hf}$ in the rocks and ores of the Norilsk deposits. Geochem. Int. 2018, 56, 46-64. [CrossRef]

(C) 2020 by the authors. Licensee MDPI, Basel, Switzerland. This article is an open access article distributed under the terms and conditions of the Creative Commons Attribution (CC BY) license (http://creativecommons.org/licenses/by/4.0/). 